\title{
Use of peptide libraries for identification and optimization of novel antimicrobial peptides.
}

\author{
Martin Ashby $^{a}$, Asya Petkova ${ }^{\text {a\# }}$, Jurnorain Gani ${ }^{\mathrm{a}}$, Ralf Mikut ${ }^{\mathrm{b}}$ and Kai Hilpert ${ }^{\mathrm{a}}$ \\ \# Authors contributed equally \\ a Institute of Infection and Immunity, St George's University Of London, Cranmer Terrace, London SW17 ORE, UK \\ ${ }^{b}$ Institute for Applied Computer Science, Karlsruhe Institute of Technology, Hermann-von-Helmholtz-Platz 1, 76344 \\ Eggenstein-Leopoldshafen, Germany
}

\author{
* Corresponding Author \\ Kai Hilpert \\ Institute of Infection and Immunity \\ St George's University of London \\ Jenner Wing, Second floor, Room 2.215C \\ Cranmer Terrace \\ London \\ SW17 0RE \\ UK
}

\begin{abstract}
The increasing rates of resistance among bacteria and to a lesser extent fungi have resulted in an urgent need to find new molecules that hold therapeutic promise against multidrug-resistant strains. Antimicrobial peptides have proven very effective against a variety of multidrug-resistant bacteria. Additionally, the low levels of resistance reported towards these molecules are an attractive feature for antimicrobial drug development. Here we summarise information on diverse peptide libraries used to discover or to optimize antimicrobial peptides. Chemical synthesized peptide libraries, for example split and mix method, tea bag method, multi-pin method and cellulose spot method are discussed. In addition biological peptide library screening methods are summarized, like phage display, bacterial display, mRNA-display and ribosomal display. A few examples are given for small peptide libraries, which almost exclusively follow a rational design of peptides of interest rather than a combinatorial approach.
\end{abstract}

Keywords: Antimicrobials, antimicrobial peptides, resistance, multidrug- resistance, peptide libraries, spot synthesis,

\section{Antimicrobial resistance}

The use of antibiotics since the early $20^{\text {th }}$ century has helped reduce death and illness associated with infectious diseases [1]. Antibiotics are not only used to treat existing bacterial infections but are also commonly used as prophylaxes for many different medical procedures, for example operations and transplants. Antibiotics are therefore a critical pillar in medicine and arguably one of the greatest triumphs in the history of modern medicine. Antibiotics were first discovered in the $1930 \mathrm{~s}$ and made publically available soon after, however within a few years resistance had already been reported among the sulphonamide class, the first antibiotics to be discovered [2]. Over the years there has been a huge surge in antibiotic resistance due to their wide availability, indiscriminate use (sore throat, neck pains, common colds and viral infections) and availability in unregulated markets[3]. Patients being incompliant by not finishing the course of medication or stockpiling for future use, and overuse in animal husbandry has further exasperated the problem[4]-[6].
Recently the emergence of multidrug-resistance (MDR) and extensive drug-resistant (XDR) organisms has been a more alarming issue. MDR usually occurs in a healthcare environment and mostly in situations where the patient is in a critical or vulnerable condition, such as those in intensive care and neonatal units[3],[7]. Bacteria which have developed MDR phenotypes include Methicillin resistant Staphylococcus aureus (MRSA), Vancomycin Resistant Enterococci (VRE) and MDR Mycobacteria tuberculosis. There have been many reported cases of extensively drug resistant $M$. tuberculosis (XDR-TB) [8], and even reports of total drug resistance (TDR-TB) [9]. MDR is also seen amongst a group of Gram positive and Gram negative bacteria, which have been dubbed the "ESKAPE" group (Enterococcus faecium, Staphylococcus aureus, Klebsiella pneumoniae, Acinetobacter baumannii, Pseudomonas aeruginosa and Enterobacter spp.) [10]. These pathogens are of emerging clinical importance due to their prevalence in nosocomial (especially in intensive care units) and community settings. 
Since the golden age of antibiotic discovery in the mid-1900s the development of new antibiotics decreased significantly (Figure 1) thus creating an urgent need for the development of novel antimicrobials that can kill multidrug- resistant bacteria [11].

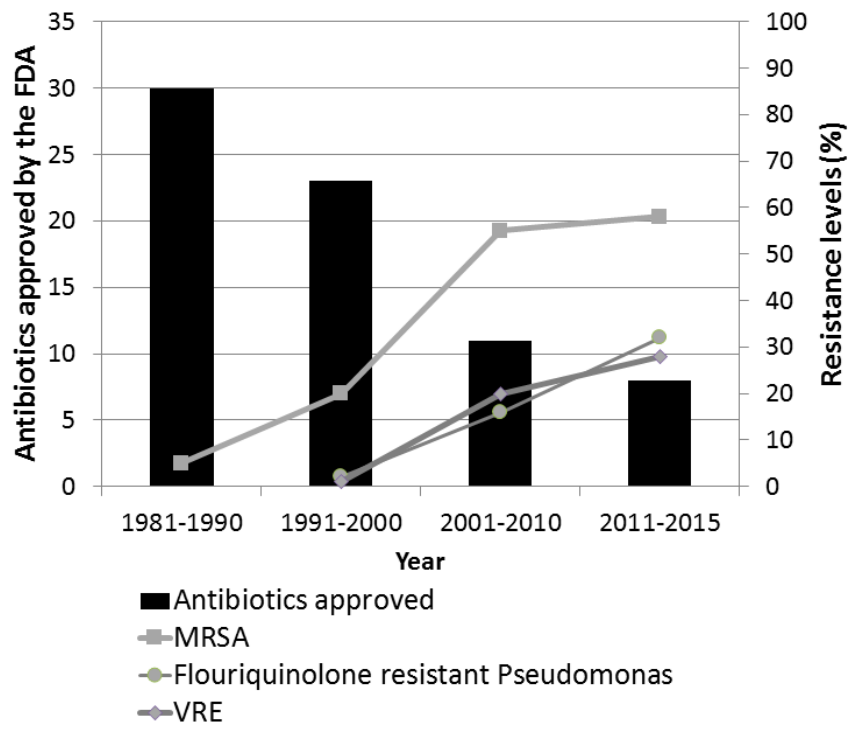

Figure 1. Decrease in antibiotic approval by the FDA has coincided with an increase in the resistance of pathogens to currently available drugs, creating an urgent need for novel antimicrobial development. Adapted from [10],[12],[13]

\section{Antimicrobial peptides}

Antimicrobial peptides have recently been receiving much attention due to several attributes that make them attractive candidates to treat multidrug-resistant infections. Perhaps most importantly is the fact that they have shown activity towards a wide spectrum of pathogens including gram positive and gram negative bacteria [14], fungi[15] viruses[16], protozoa [17] and organisms with multidrugresistant phenotypes [18]-[20]. This is coupled with the fact that antimicrobial peptides (AMP's) have shown a lower propensity for inducing bacterial resistance compared to other antibiotics [21] and they also have the ability to target metabolically inert cells e.g. those in latent infections [22] and biofilms [11].

Whilst the design and synthesis of novel antimicrobial peptides is becoming increasingly common in laboratories worldwide, for a long time nature has utilised antimicrobial peptides in all kingdoms of life to defend against pathogenic invasion, or in the case of microorganisms to ward off competitors for nutrients. Some examples of peptides found in nature can be seen in Table 1. In many cases utilisation of these peptides by the immune system is not limited to their direct killing of pathogens as they can also lead to an induction of chemokine release[23], modulation of inflammatory response[24] and promotion of wound healing [25].

Antimicrobial peptides (AMP's) are not restricted to one mode of action, in fact several cellular target sites have been reported[15],[26]-[28]. The most commonly described target for antimicrobial peptides is the microbial cell membrane. Due to the fact that the prokaryotic membrane generally contains a higher proportion of negatively charged phospholipids then mammalian cell membranes[29], and that most AMP's have a net positive charge [30] peptides are able to selectively interact with microbial cells. However, this selectivity is not always very pronounced and one of the challenges to identifying therapeutically viable antimicrobial peptides is the identification of those with an optimised therapeutic window.

Numerous different peptides have been identified that can cause extensive membrane disruption, depolarisation and cell death [31]-[33]. For these membrane active peptides at least three different mechanisms have been identified. A barrel stave model of membrane pore formation whereby peptides insert into the lipid bilayer in a perpendicular manner. A toroidal model where peptides are inserted into the membrane perpendicularly but the resulting pore is lined by intercalated peptide and lipid head groups. The carpet mechanism where peptides remain parallel with the membrane but have a detergent like effect leading to significant membrane disruption [34]. Although the disruption of microbial membranes is the most studied mechanism by which peptides cause cell death it is by no means the only mechanism. The vast heterogeneity of antimicrobial peptides is illustrated by the fact that inhibition of cell walls synthesis, inhibition of DNA, RNA and protein synthesis, inhibition of septum formation, binding and sequestering of lipid II, and inhibition of ATP dependent enzymes have all been proposed as mechanisms which may individually or simultaneously lead to cell death[15],[27],[35]-[39].

There are some common features among AMP's, many are amphipathic, contain 12-50 amino acids and possess a net positive charge. There are however exceptions to the rule as antimicrobial activity has been found in peptides ranging from $<10$ to $>100$ amino acids in length [40] and in anionic peptides[41]. The number of possible amino acid combinations that can be achieved within this range is vast, however this number is further amplified when considering the wide spread use of non-natural amino acids and chemical modifications. This diversity is well illustrated by databases of antimicrobial peptides such as the APD2 database which currently lists 2523 unique AMP sequences found in nature [40]. A range of different structures exists among these antimicrobial peptides including $\alpha$-helices e.g. magainin[42], $\beta$-sheets e.g. defensins[43] and random coils e.g. histatins[44] (Figure 2). However, many antimicrobial peptides are believed to undergo structural alteration during transition from aqueous environments to amphiphilic environments such as those within cell membrane [44],[45]. 


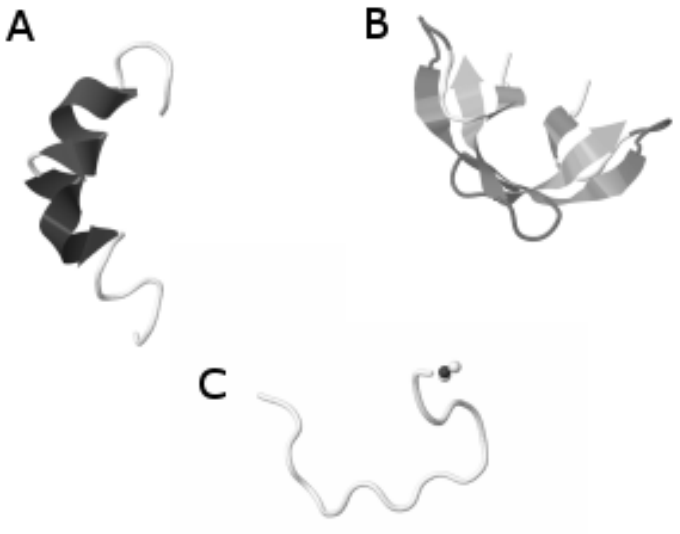

Figure 2. Structures of different antimicrobial peptides. A. $\alpha$ helix, Magainin in solution NMR; (PDB: 2LSA) B. $\beta$-sheets, HNP-3 Defensin via X-Ray diffraction; (PDB: 1DFN) C. Random coil, Indolicidin in solution NMR (PDB: 1QXQ)

In this review we will focus on novel antimicrobial peptide discovery or optimisation of existing peptides through the use of both combinatorial libraries prepared through chemical synthesis and biological libraries. Additionally due to the fact that a lot of the literature from the AMP field describes the synthesis of libraries with a small number of representatives obtained by solid phase peptide synthesis we will also include a third class - small peptide libraries. Some examples of AMP's found using various peptide libraries have been given in Table 2.

\section{Chemical synthesized Peptide Libraries}

\section{1. "Split and Mix" Method}

The "Split and Mix" method is used for the preparation of "combichem" libraries of peptides and is based on the Merrifield method for solid phase peptide synthesis[46]. Initially Boc chemistry was used for the $\mathrm{N} \underline{\alpha}$ protection of the amino group of an amino acid. The method was designed by A. Furka and it was first published as a poster on the $14^{\text {th }}$ International Congress of Biochemistry in Prague in 1988 with the title "Cornucopia of peptides". Following the introduction of the base-liable Fmoc group for $\mathrm{N} \underline{\alpha}$ protection "split and mix" libraries were also prepared using Fmoc chemistry. This method does not differ much from the conventional Solid Phase Peptide Synthesis (SPPS), however it includes dividing the resin into equal portions, then coupling each of the portions with one amino acid at a time. This is then followed by mixing of the resin portions and again dividing it before the next coupling of the subsequent amino acid takes place [47],[48] (see Figure 3B). Distinctive features of this method are that it can result in obtaining all possible combinations between the individual building blocks (combinatorial principle) and also the compounds synthesized are believed to be in one to one molar ratio, which is important for subsequent screening methods. The "split and mix" is a parallel synthesis on solid support that can either result in a mixture of compounds if the resin beads are combined prior to cleavage or if the resin beads are separated, then individual compounds can be cleaved and tested (one bead one sequence). Both mixtures and individual sequences produced by combinatorial approaches need the use of deconvolution methods to decipher the component or components with the desired activity [47]

In the search of AMPs with improved activities the "combichem" approach was first explored by the group of Blondelle et al. in 1994[49]. Their work focused on the preparation of combinatorial libraries using tetrapeptides $\mathrm{N}$ acetylated (Ac-UZZZ-NH$)$ and non-acetylated $\left(\mathrm{UZZZ-NH} \mathrm{N}_{2}\right)$ template sequences, where the $U$ position is a defined amino acid and the $\mathrm{Z}$ position can be taken by any L-, D-, or unnatural amino acid (in total 56 building blocks were used as D- and L-Cys were omitted for the $\mathrm{Z}$ position). After obtaining the 58 different peptide mixtures, each of which containing $56^{3}$ or 175,616 different peptides, they were screened for anti-staphylococcal activity and the nonacetylated peptides showed better activity. An iterative selection procedure was then performed aiming to identify the sequences with the highest antimicrobial activity[49]. The peptide mixture ( $\alpha$ Fmoc-elys)ZZZ-NH ${ }_{2}$ showed the greatest activity against $S$. aureus with a MIC ranging from 78 to 156 $\mu \mathrm{g} / \mathrm{ml}$. Then based on these results a new mixture of peptides was synthesized using ( $\alpha$ Fmoc-elys)ZZZ- $\mathrm{NH}_{2}$ as a template, where the second position of the library was now defined. After three iteration steps two peptides showed MIC values against $S$. aureus and $S$. sanguis ranging from 3 to $4 \mu \mathrm{g} / \mathrm{ml}$. Interestingly, the same peptides were weakly active against $E$. coli with MIC values ranging from 31-128 $\mu \mathrm{g} / \mathrm{ml}$. Two years later Blondelle et al. published another paper focusing this time on antifungal hexapeptide combinatorial libraries prepared using the 20 natural L-amino acids. Solution mixtures of peptides were obtained after using the "split and mix" technique and were then tested in microdilution assays in a 96 well plate format from which $\mathrm{IC}_{50}$ values against Candida albicans were determined. One of the mixtures (Ac$\mathrm{OOXXXX}-\mathrm{NH}_{2}$ where $\mathrm{O}$ is a defined amino acid and $\mathrm{X}$ can be any of the 20-L amino acids) showed strong anti-Candida activity. An iterative approach was applied to the mixture and one amino acid at a time was defined, the process consisted of four steps and each step resulted in a twenty times lower number of components in the mixture. The last step identified peptide Ac-RRWCKR-NH $\mathrm{N}_{2}$ as the most potent anti-Candida peptide. The MIC range of the peptide against $C$. albicans was determined to be between $67-130 \mu \mathrm{g} / \mathrm{ml}$. Additionally some of the peptides from the Ac-OOXXXX- $\mathrm{NH}_{2}$ library showed broad spectrum antimicrobial activity against both $S$. aureus and $E$. coli with no or low haemolytic activity[50]. 
Table 1. Examples of antimicrobial peptides discovered in nature

\begin{tabular}{|c|c|c|c|c|c|c|c|}
\hline Name & Origin & Sequence & Length & Net Charge & $\begin{array}{l}\text { \% } \\
\text { hydrophobicity }\end{array}$ & $\begin{array}{l}\text { Reported antimicrobial } \\
\text { Activity }\end{array}$ & Ref \\
\hline Temporin $\mathrm{K}$ & $\begin{array}{l}\text { European common frog, Rana } \\
\text { temporaria }\end{array}$ & LLPNLLKSLL & 10 & 2 & $60 \%$ & Gram + & [51] \\
\hline Bactenecin & Bovine neutrophils. Bos Taurus & RLCRIVVIRVCR & 12 & 4 & $66 \%$ & Gram +/- & [52] \\
\hline Halictine & Bee venom, Halictus sexcinctus & GMWSKILGHLIR & 12 & 3 & $50 \%$ & Gram +/- antifungal & [53] \\
\hline Gramicidin B & Bacteria, Bacillus brevis & VGALAVVVWLFLWLW & 15 & 0 & $93 \%$ & Gram +/- & [54] \\
\hline Tachyplesin III & $\begin{array}{l}\text { Horseshoe crab, Tachypleus } \\
\text { gigas }\end{array}$ & KWCFRVCYRGICYRKCR & 17 & 7 & $47 \%$ & Gram +/- & [55] \\
\hline Duramycin & $\begin{array}{l}\text { Bacteria, } \\
\text { Streptoverticillium } \\
\text { griseoverticillatum }\end{array}$ & CKQSCSFGPFTFVCDGNTK & 19 & 1 & $36 \%$ & Gram + & [56] \\
\hline Hainanenin 1 & $\begin{array}{l}\text { Hainan cascade-frog, Amolops } \\
\text { hainanensis }\end{array}$ & FALGAVTKLLPSLLCMITRKC & 21 & 3 & $61 \%$ & Gram +/- antifungal & [57] \\
\hline Hominicin & $\begin{array}{l}\text { Bacteria } \\
\text { Staphylococcus hominis }\end{array}$ & ITPATPFTPAIITEITAAVIA & 21 & -1 & $57 \%$ & Gram +/- & [58] \\
\hline $\begin{array}{l}\text { Human } \\
\text { neutrophil } \\
\text { peptide-1 }\end{array}$ & Humans, Homo sapiens & ACYCRIPACIAGERRYGTCIYQGRLWAFCC & 30 & 3 & $53 \%$ & $\begin{array}{l}\text { Gram +/- antiviral, antifungal, } \\
\text { antiparasitic, anti-HIV }\end{array}$ & [59] \\
\hline Pardaxin 1 & $\begin{array}{llr}\text { Red } & \text { Sea } & \text { moses } \\
\text { sole, } & \text { Pardachirus } & \text { pavoninus }\end{array}$ & GFFALIPKIISSPLFKTLLSAVGSALSSSGEQE & 33 & 0 & $45 \%$ & Gram +/- & {$[60]$} \\
\hline Nisin A & Bacteria, Lactococcus lactis & $\begin{array}{l}\text { ITSISLCTPGCKTGALMGCNMKTATCHCSIHV } \\
\text { SK }\end{array}$ & 34 & 3 & $44 \%$ & Gram + & [61] \\
\hline $\begin{array}{l}\text { Human beta- } \\
\text { defensin } 1\end{array}$ & Humans, Homo sapiens & $\begin{array}{l}\text { DHYNCVSSGGQCLYSACPIFTKIQGTCYRGKA } \\
\text { KCCK }\end{array}$ & 36 & 4 & $36 \%$ & Gram +/- antiviral, & [62] \\
\hline LL-37 & Humans, Homo sapiens & $\begin{array}{l}\text { LLGDFFRKSKEKIGKEFKRIVQRIKDFLRNLVPR } \\
\text { TES }\end{array}$ & 37 & 6 & $35 \%$ & $\begin{array}{l}\text { Gram +/-antiviral, antifungal } \\
\text { antiparasitic }\end{array}$ & [63] \\
\hline Buforin I & Toad, Bufo bufo gargarizans & $\begin{array}{l}\text { AGRGKQGGKVRAKAKTRSSRAGLQFPVGRV } \\
\text { HRLLRKGNY }\end{array}$ & 39 & 12 & $28 \%$ & Gram -/+ antifungal, & [64] \\
\hline Lucifensin & Bottle fly, Lucilia sericata & $\begin{array}{l}\text { ATCDLLSGTGVKHSACAAHCLLRGNRGGYCN } \\
\text { GRAICVCRN }\end{array}$ & 40 & 4 & $45 \%$ & Gram + & [65] \\
\hline
\end{tabular}


Shortly after their discovery combinatorial approaches started incorporating a focus on a rational design of molecules rather than using completely random strategies for library construction. One of the studies that illustrates the evolution in the combinatorial approach is described by Rausch et al, focusing on the rational design of beta-sheet pore forming peptides [66]. The peptides for the study were synthesized with the "split and mix" method and a 26 residue framework was used in the construction of the library. The rationale of the group was aimed towards discovering a new sequence motif in a peptide, which will promote self-assembly into membrane spanning beta-sheets. The 26 residue framework of a beta-sheet prototype structure was designed to resemble common features associated with pore-forming, naturally occurring peptides known to possess a beta-structural motif. These features included a short amphipathic dyad repeat followed by a region consisting of basic residues[48]. Dyad repeats are characteristic features of beta-barrel structures and are encoded in the amino acid sequences of the membrane interacting surface of the beta barrels. The dyad repeat pattern consists of alternating amino acid residues oriented either towards the lipid bilayer or towards the barrel interior[67]. The 26 residue prototype hairpin structure included two dyad repeat motifs separated by a four residue turn structure. Six positions were chosen to be the combinatorial sites in the 26 amino acid framework and three of them were juxtaposed in the dyad repeats of the hairpin structure. A hydrophobic variable region designated $\mathrm{O}_{\mathrm{H}}$ (G,A,V,I,L,F,Y) (where amino acids are described with their one letter code) was chosen to be the start of the putative hairpin structure in the beginning of both of the strands. The $\mathrm{O}_{\mathrm{H}}$ region of the strands was followed by a $\mathrm{O}_{\mathrm{G} / \mathrm{S}, \mathrm{T}}$ site that would incorporate glycine and either serine or threonine as these are the three most abundant amino acids on the inside of a membrane beta-barrel structure [68]. Just one position away from the $\mathrm{O}_{\mathrm{G} / \mathrm{S}, \mathrm{T}}$ site the $\mathrm{O}_{\mathrm{P}}$ region was located and the full set of acidic, basic and polar amino acids was varied within this region. Rausch et al. demonstrated a combinatorial library construction using the one bead, one sequence approach of screening. The beads were separated into 96 well plates and the potency of membrane permeabilization of each one of the sequences after cleavage from the photoliable linker was assessed by using lipid bilayer vesicles. The vesicles incorporated lanthanide metal terbium $\left(\mathrm{Tb}^{3+}\right)$, while dipicolinic acid (DPA) was added to each of the wells of the 96 well plate. If the peptides were able to lyse the vesicles then a $\mathrm{Tb}^{3+} / \mathrm{DPA}$ complex is formed. $\mathrm{Tb}^{3+} / \mathrm{DPA}$ complex is able to luminesce and the results can be read visually. The high throughput assay identified 30 peptides with the strongest ability to permeabilize lipid bilayers and the sequences of the strongest acting peptides were defined by Edman degradation. In all of the strongest acting peptides a conserved sequence motif was found to be present.

In a different study it was shown that short peptides (9-15 amino acids in length) obtained from "split and mix" combinatorial libraries were able to permeabilize artificial bilayers [69], however a shared sequence motif amongst them was not identified. On the other hand the most active peptides shared some common compositional features, secondary structure and core hydrophobicity. Based on these results the authors hypothesized that membrane permeabilization is dependent on the so called interfacial activity or the ability of the peptide to alter the packaging of lipids and their organisation in the membrane rather than formation of stable transmembrane pores. Interestingly Rausch et al. also initially thought the beta sheet peptides were able to form stable transmembrane pores[66], however this was proven to be an incorrect hypothesis in their later work where they showed beta-sheet peptides with the strongest potential to permeabilize vesicles are not partitioning in a stable transmembrane conformation, but are rather thought to cause transient pores[70].

In a recent study by Krauson et al[71] an iterative combinatorial library was synthesised based on the 26 residue consensus sequence of membrane permeable, beta sheet antimicrobial peptides found by Rausch et al[70]. Six positions in the 26 mer peptide were subject to substitution with different amino acids. The general structure of the peptide was: RRGxxLxLALAKDGWALMLxLxxGRR-NH $\mathrm{N}_{2}$, where (x) denotes the variable positions. Again an artificial lipid vesicle assay was used for the screen of the new library but this time with increased stringency in the peptide to lipid ratio. In addition to that, the assay was able to identify peptides at equilibrium i.e. peptides able to maintain long term membrane disruption as opposed to causing transient interactions on the surface of the vesicles. The study identified much stronger acting peptides in a peptide to lipid ratio of 1:1000 in comparison to 1:50 for the representatives of the first library, implying that the optimised peptides might have adopted a membrane spanning beta-sheet conformation. Interestingly the most potent candidates showed inconsistent results when tested against biological membranes, thus concluding that the vesicle-based screen can be used as a powerful tool in the first line of selection of potential candidates. However in order to optimise and improve the structures that hold promise a combination of methods that translate better in vivo should be applied. 


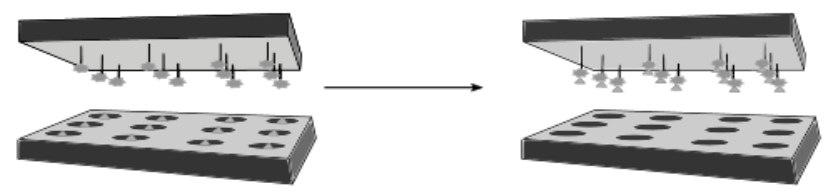

B
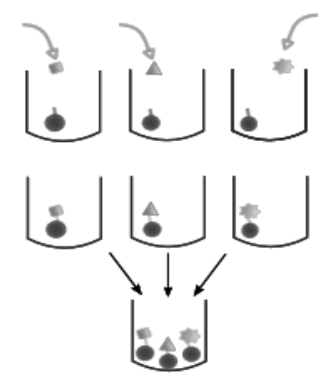
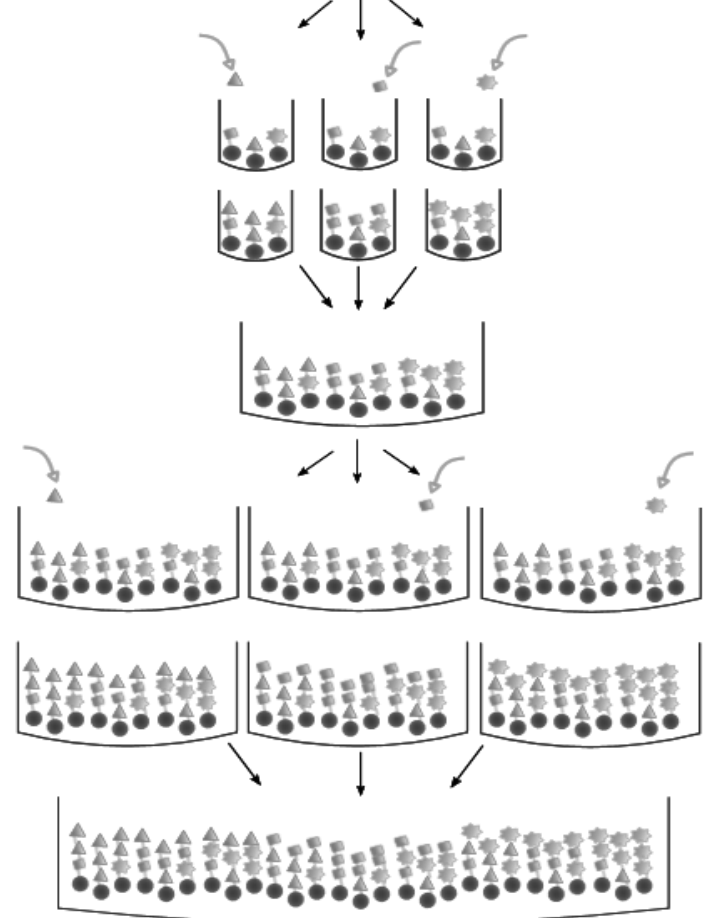

C
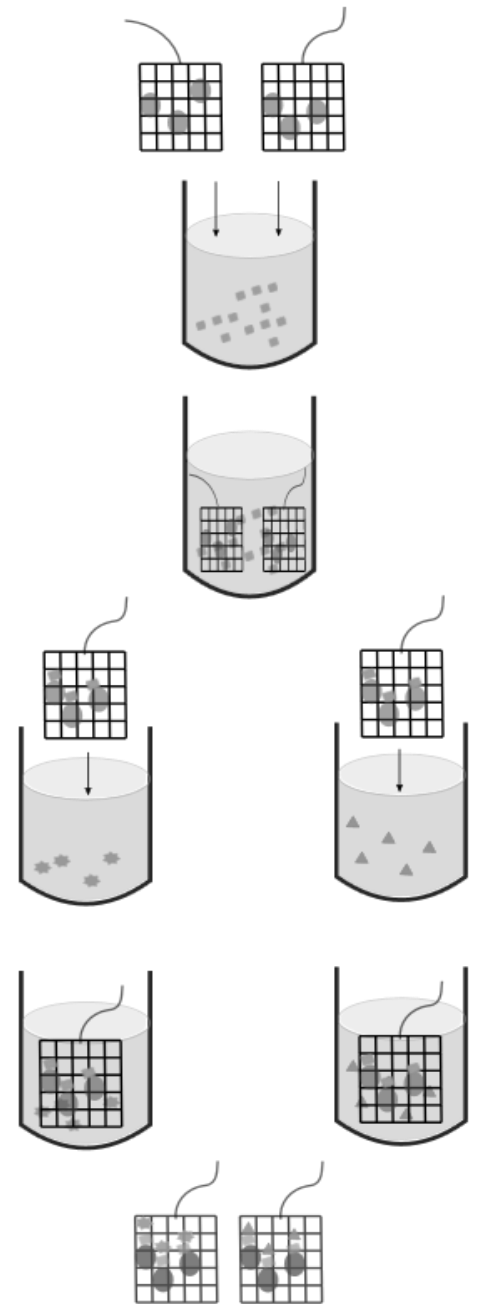

Figure 3. Schematic representation illustrating the three methods for parallel synthesis on resin for the preparation of combinatorial libraries. A. "Multi pin" method[72]: 96 polypropylene pins with poly acrylic acid pin heads mounted on a frame above a 96 well plate, where each well contains an activated amino acid solution (left panel). In order for elongation of the peptide chain to take place the multi pin frame has to be dipped in the wells of the 96 well plate (right panel). B."Split and mix" method[73]: the synthesis of a tripeptide with all the possible combinations obtained from coupling of the individual amino acids is illustrated (modified from[47]) . Initially the resin beads (illustrated as spheres) are separated into three reactors. Then a coupling step with three different amino acids takes place. After the coupling step the resin beads are combined into one reactor. This is then followed by a subsequent splitting of the resin into equal portions in three separate reactors, where a second coupling takes place. The resin beads with the prepared

dipeptides are then again combined into one reactor. The procedure is repeated and finally tripeptides are obtained containing all possible combinations of the three amino acids. C. Tea-bag method[74]: polypropylene mesh bags are filled with resin beads and are placed into a beaker with an activated amino acid solution. Depending on the sequence to be synthesized the bags can be then dipped into different beakers each dedicated for the desired amino acid solution. 


\section{2. “Tea bag" method}

Another approach for "combichem" libraries preparation using standard SPPS synthesis is the "tea bag" method designed by R. A. Houghten in 1985[74] (see Figure 3C). The method uses labelled polypropylene mesh bags (15 $\mathrm{mm}$ x $20 \mathrm{~mm}$ ) containing resin beads onto which the peptides are synthesised. The method includes all the steps of a standard solid phase peptide synthesis protocol. Similarly to the "split and mix" method it was initially designed to be used with Boc chemistry. Later on a protocol for peptide synthesis with "tea bags" using Fmoc chemistry was developed [75]. The washing and deprotection steps are performed together and the bags are combined for convenience. It is only the coupling step that is done individually in dedicated beaker reactors.

Jofre et al. synthesized a library of peptide analogues between 16 and 20 amino acids in length derived from the infectious pancreatic necrosis virus (IPNV) viral protein VP2 [76]. The original p20 peptide and all the variants showed activity against a variety of Gram-negative bacteria (V.ordalii, V. alginolitycus, V.anguillarum, A hydrophila, E.coli) and Gram positive bacteria (S.epidermidis, M.luteus) with MIC values ranging from $25-100 \mu \mathrm{M}$. Furthermore the peptides showed no toxicity against eukaryotic cells (CHSE-214 or Chinok salmon embryo cells) at 10 times the concentration used for the antimicrobial assays. One of the peptides (GIM 444) showed a MIC of $25 \mu \mathrm{M}$ against $E$. coli, $V$. alginolitycus, $V$. ordalli and a MIC of $50 \mu \mathrm{M}$ against S.epidermidis.

\section{3. "Multi pin" method}

The method was originally designed by Geysen et al. for a 96 well plate format based screen [72]. Similarly to the other methods mentioned above the "multi-pin" is a solid phase peptide synthesis where the peptides synthesized are attached to the tip of a polypropylene pin $(4 \mathrm{x} 44 \mathrm{~mm})$ functionalised by acrylic acid [47], which polymerizes on the surface of the pin so poly acrylic acid is formed. The pins are then mounted on a frame with the same dimensions as a 96 well microtiter plate. The wells of such a plate are then filled with activated amino acid solutions in which the multi-pin frame can be positioned so the polypropylene pins are placed in the activated monomer solution (see Figure $3 \mathrm{~A})$. The scale of the technique can be very small $(50 \mathrm{nmol})$, however such a scale is mainly used in binding experiments for epitope mapping of antibodies by screening the peptides afterwards using ELISA. The method was later developed to incorporate chemical linkers, which can be easily cleaved so the synthesized peptides can be screened in solution [77]. This also resulted in increased scale of the synthesis and multi-milligram quantities of the synthesized peptides, which also made their purification possible. For example
Brogden et al. reported on the antimicrobial activity of propeptide fragments which were part of larger inactive proteins (zymogens) [78] with conserved homopolymeric regions of aspartic acid. These conserved negatively charged fragments can be part of hormones, enzymes and cationic proteins within the same animal species, however they can also be conserved between different animal species [78]. The study focused on the antimicrobial activities of propeptide fragments of ovine trypsinogen activated protein (TAP) and frog (Xenopus leavis) PYL activation peptide. The fragments were synthesized using the multi-pin method and were then cleaved, purified and screened for their antimicrobial activity. The results showed that the peptides were most active against Gram-negative bacteria ( $K$. pneumonie, E. coli and $P$. heamolytica) with MICs ranging from $0.08-0.90 \mathrm{mM}$, but they were less active against Grampositive bacteria with MIC's ranging between 0.94 to 2.67 $\mathrm{mM}$ (E. faecalis and $S$. aureus). Based on their results the authors were able to conclude that in addition to their charge neutralizing properties in larger proteins, propeptide fragments rich in negatively charged amino acids also have innate immune functions and might offer potential as new antimicrobials.

Iwasaki et al modified a short antimicrobial peptide fragment of celeoptericin-A[79]. Celeoptericin-A is a protein isolated from the larvae of a beetle Allomyrina dichotoma after challenging with E. coli. Iwasaki et al. synthesized 53 overlapping sequences 20 amino acids in length with a frame shift of two residues by using the "multipin" method. Two of the peptide fragments showed activity against $E$. coli, but not against $S$. aureus. These peptides were then used to create a second sub-library of peptides with increased hydrophobicity and net charge. From the sub-library one of the analogues showed greater activity than celeoprericin-A against $E$. coli $(11 \mu \mathrm{g} / \mathrm{ml}$ in comparison to $31.9 \mu \mathrm{g} / \mathrm{ml})$. Furthermore the peptide was also active against $S$. aureus, however less active than the full length celeoptericin-A.

\subsection{Libraries on cellulose support (SPOT synthesis)}

Peptide synthesis on a cellulose membrane is another way of creating peptide libraries. Defined peptides as well as combinatorial peptides can be synthesized. This method was developed by R. Frank in Germany more than 20 years ago[80]. Simple filter paper, like Whatman Chr1, 50 or 540 can be used for the synthesis. In addition, specially optimized cellulose membranes for binding assays are commercially available [81]. The free hydroxyl groups of the cellulose are modified by natural or non-natural amino acids in order to have reactive amino groups available. Often a spacer is introduced to improve binding assays. Afterwards the peptide synthesis follows standard Fmoc-

Figure 4. Substitution analysis of the peptide Bac034 (VRLRIRVAVIRA-NH 2 ), whereby the 12 mer peptide is substituted with all common proteinogenic amino acids barring cysteine, modified from Hilpert et al. 2006 [86]. The data can be plotted on a heat map where the darkest shaded cells represent the most active peptides, white is inactive. 


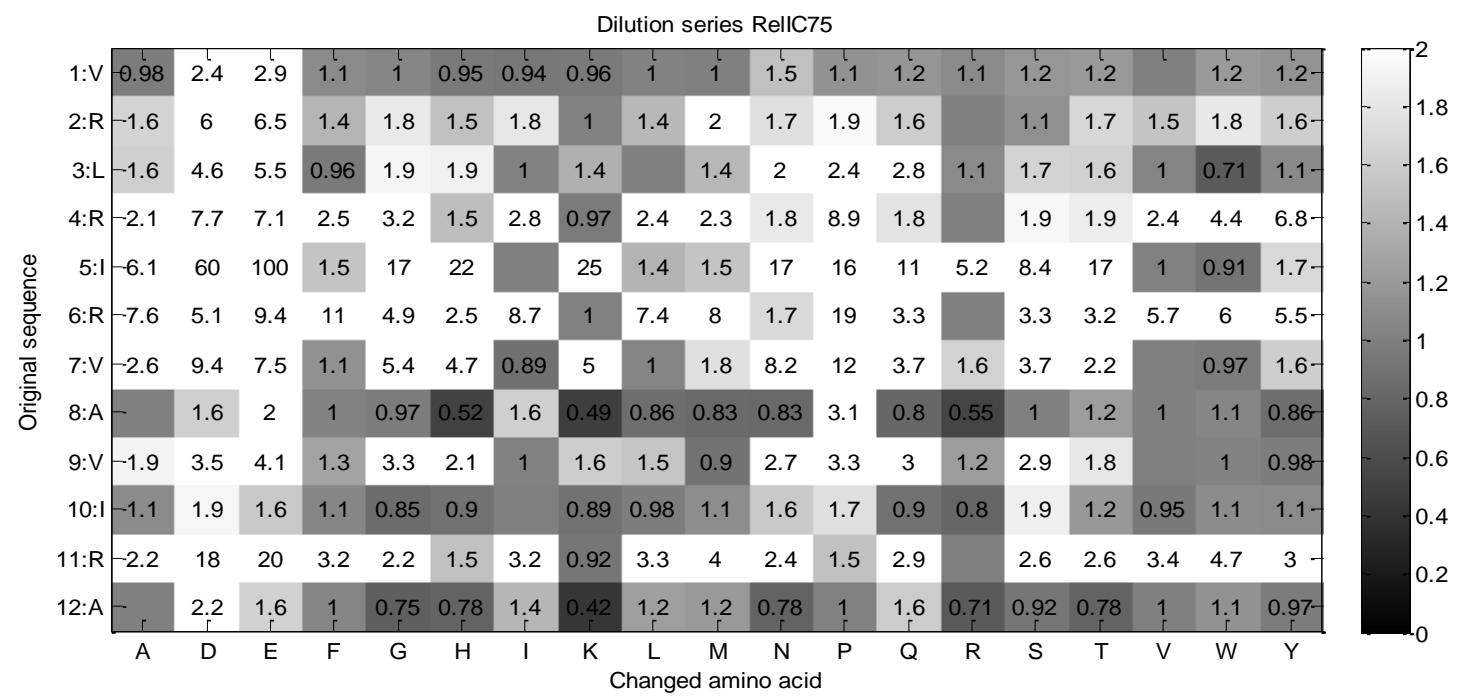

chemistry. A detailed protocol of the method was published previously [82]. For binding assays small spots (about $0.1 \mu 1$ spot volume) are sufficient for the experiments, whereas for other in vitro experiments where a higher yield is required large peptide spots (about $1.2 \mu \mathrm{l}$ spot volume) are used. Typically 6000 - 8000 small spots or 600 - 800 large spots will fit on one cellulose sheet with a size of 18 x $29 \mathrm{~cm}$.

It was reported that using glycine as a linker between the hydroxyl groups of the cellulose and the first amino acids of the desired peptides yields a peptide density of up to $1.9 \mu \mathrm{mol} / \mathrm{cm}^{2}[83]$. Optional, the peptides can be cleaved from the cellulose filter using different methods, ammonia gas being the most common [81]. In 2005 Hilpert et al. described the application of peptides synthesized by the spot synthesis method in the field of antimicrobial peptides [84]. Large spots were synthesized using glycine as a linker. Peptides were cleaved from the cellulose by ammonia vapour and each spot was punched out individually and transferred into a 96 well plate. Peptides were dissolved in autoclaved distilled water [85] Bac2A (RLARIVVIRVAR), a linear variant of the bovine cathelicidin bactenecin (RLCRIVVIRVCR), was used to study the interaction with Pseudomonas aeruginosa in detail. In this study a bioluminescent $P$. aeruginosa was used to gain a fast and sensitive read out. A substitution analysis, comprising of 228 systematic substitutions of Bac $2 \mathrm{~A}$, was synthesized. For each of the peptides a dilution series was performed and based on the concentration dependent activity against $P$. aeruginosa an $\mathrm{IC}_{50}$ for each peptide was calculated. This value was compared to the original activity of Bac2A and deeper and systematic insight of the interaction with the bacterium was achieved. Several single substituted peptides were synthesized on resin, purified and an MIC against different pathogenic bacteria and one yeast was performed to validate the data. An example of typical data obtained from substitution analysis is given in figure 4 . The MIC of Bac2A against $P$. aeruginosa was determined as $50 \mu \mathrm{g} / \mathrm{ml}$, using combinations of favourable substitutions within Bac2A the MIC improved to $2 \mu \mathrm{g} / \mathrm{ml}$ for the peptides RRWRIVVIRVRR-NH $\mathrm{N}_{2}$ and RRWRIVVIRVRR$\mathrm{NH}_{2}$. Similar investigations were performed on Bac034 (VRLRIRVAVIRA-NH $\mathrm{N}_{2}$, where a substitution analysis resulted in a deeper understanding of the interaction with $P$. aeruginosa and also in the identification of two novel peptides with improved antimicrobial activity VRLRIRVRVIRK-NH $\mathrm{N}_{2}$ and KRWRIRVRVIRK-NH $\mathrm{N}_{2}$ both showing an MIC value of $3 \mu \mathrm{g} / \mathrm{ml}$ against $P$. aeruginosa compared to $25 \mu \mathrm{g} / \mathrm{ml}$ of the Bac034 [86].These two examples show that this method can be successfully used to systematically optimize antimicrobial peptides.

In the same publication the authors show that short antimicrobial peptides present a surprising feature [86]. In total, 49 scrambled variants of Bac2A (all different sequences but same amino acids) were synthesized and tested against $P$. aeruginosa. Within the 49 scrambled peptides some had antimicrobial activity superior or similar to Bac2A but also some were weaker or inactive. This experiment indicated the complexity of requirements for short active peptides. In addition, to add more complexity, the paper shows that a substitution within a 12 mer peptide will influence the effect of other substitutions at distant positions, here described by in initial substitution at position 3 effecting the activity of a second substitution site at distance of 8 amino acids [86].

A different approach to discovering novel antimicrobial peptide sequences is to screen biased or unbiased peptide libraries of random peptides. A peptide library containing 200 members of unbiased random peptides was synthesized and screened against $P$. aeruginosa [87]. Only peptides with weak $(53 \%)$ or no activity $(47 \%)$ were found. Based on the data from earlier experiments [82],[86] a new biased random peptide library was designed, synthesized and screened against $P$. aeruginosa. Here the amino acid occurrence probability within a random peptide creation was biased towards occurrence seen in former experiments with short active cationic antimicrobial peptides. The new peptide library comprising of 943 peptides showed $3.2 \%$ peptides with superior antimicrobial activity, $18.2 \%$ were active, $68.4 \%$ were weakly active and $10.2 \%$ were inactive [87]. A subsequent biased library was prepared and showed an improvement in activity, resulting in $3.2 \%$ superior antimicrobial peptides, $26.7 \%$ active, $61.1 \%$ weakly active and $8.9 \%$ inactive [87]. To further improve 
the activity all the obtained data were used for a quantitative structure-relationship (QSAR) approach. Here a three dimensional structure was modelled for each peptide and 3D-sensitive properties of each peptides were obtained using 'inductive' descriptors. Using an artificial neural network (ANN) QSAR was performed and novel peptides were predicted. Highly active peptides were predicted with an accuracy of $94 \%$ [87]. The most active reported peptide KRWWKWWRR-NH2 showed a MIC of $0.7 \mu \mathrm{M}$ against $P$. aeruginosa, in addition peptide KRWWKWIRW-NH2 (MIC of $0.8 \mu \mathrm{M}$ ) was successfully tested in an infectious mouse model using a $S$. aureus infection [87]. Both peptides were also active against eight species of multidrug resistant bacteria [87]. Since the peptides showed such broad spectrum activity and as they could also kill multidrug resistant bacteria, a screen was performed against Mycobacterium tuberculosis. Tuberculosis still affects one third of the world's population and multidrug resistance is rising. Ramón-García et al. report short cationic peptides that have broad spectrum activity and can also kill $M$. tuberculosis. The most active peptide was KWLKKWIK$\mathrm{NH}_{2}$ which showed a MIC of $1.1 \mu \mathrm{M}$ against. $M$. tuberculosis [88].

The previously described examples using the spot technology utilised cleaved peptides for the screen and optimisations. It is possible to screen for tethered peptides that are antimicrobial, as shown by Hilpert et al. 2009 [89]. These tethered peptides can then be used for protecting surfaces against infections, for example implants. This type of screen requires a different chemistry since the ester between the hydroxyl groups of the cellulose and the amino acid is not stable enough and could influence the results. Cellulose-amino-hydroxypropyl ether (CAPE) linker chemistry was used to screen for surface active antimicrobial peptides [89]. A series of surface active tethered peptides were identified and subsequently developed further and grafted on polymer brushes [90]. These brushes were covalently bound to a titanium surface, a material frequently used for implants. Even tethered on the brushes peptides maintained excellent broad spectrum antimicrobial activity in vitro. Using a $P$. aeruginosa biofilm model, it was shown that these new surfaces had an extremely effective protection against biofilm formation [90]. Titanium wires carrying these new type of peptide coupled polymer brushes were used in a rat infection model and it was shown that the novel coating could protect the implants from infection [90].

Interestingly, experience gained using the aforementioned peptide libraries was used to design two new small libraries of peptides. K. Hilpert designed peptide libraries $\mathrm{HH} 1$ to HH18 and subsequently to further improve the library he designed IDR-1001 to IDR-1048. Several investigations were carried out on these libraries. For example HH2, IDR1002 and IDR-1018 were shown to be potent innate defence regulators and could protect mice against $M$. tuberculosis infections [91],[92]. Recently, it was reported that IDR-1018 has an anti-biofilm effect on several bacteria [93]

\subsection{Data analysis of peptides on cellulose spots}

The computer-based analysis of a given library can be summarized by an iterative process as shown in Figure 5. It starts with a first library version with peptide sequences and corresponding measurements for each of these peptides; see surveys in [94]-[96]. Typical measurements are binary classifications such as antimicrobial/non-antimicrobial, MIC values of peptides or dilution series of antimicrobial activity indicators such as luminescence values in luciferase assays. Various kinds of toxicity measurements can be added to rate not only the activity, but the therapeutic potential of peptides [97].

To analyse peptides, different descriptors are computed from the peptide sequences. Such descriptors are amino acid composition, aggregated descriptors of amino acids (e.g., hydrophobicity and isoelectric point) or descriptors for physico-chemical properties of complete sequences (e.g., alpha-helix propensity [98],[99]. These descriptors are aggregated by Bayes classifiers [100], Neuro-Fuzzy models [99], Artificial Neural Networks [87],[98],[101] or Support Vector Machines [98],[101] to predict activity or toxicity for unknown peptide sequences. More powerful models can be designed if activity measurements against various microbes and toxicity values are available. Such models can be used to predict and select peptides that act only against specific microbes or to avoid toxic effects against human cells. It should be noted that all models are only reliable for peptides that are similar to peptides used for model design.

Another analysis output is the result visualization using few powerful descriptors followed by the manual or the automatic generation of design rules for better peptides [101],[102]. Such rules should be understandable and based on intuitively interpretable descriptors, as e.g. amino acid compositions, promising motifs or established descriptors such as charge and hydrophobicity.

The in silico synthesis of promising peptides by these design rules enriches peptides with desired properties to be synthesised in vitro as a first candidate set. By applying the previously generated model to predict activities or toxicities, a set of most promising peptide candidates can be selected for the next iteration in the library optimization process. Such library optimizations were successfully applied for the increased activity of random and semirandom libraries against $P$. aeruginosa [87], $M$. tuberculosis [88]. 


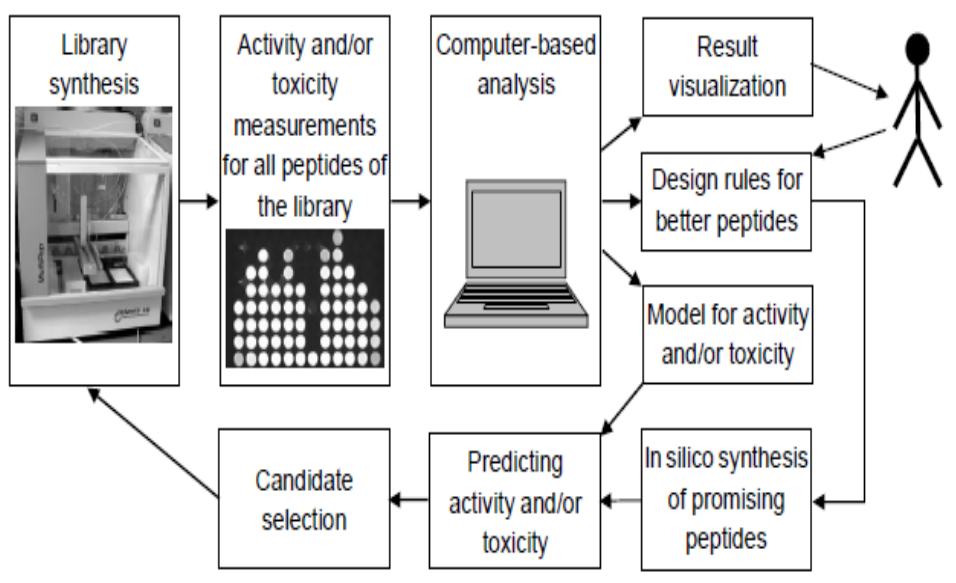

Figure 5. Optimization strategy for peptide libraries (modified from [134])

\subsection{Peptides libraries on glass slides}

Using standard peptide microarray technology tens of thousands of randomly designed peptides can be printed onto glass slides and then screened in situ against different species of bacteria[103]. In the work of Diehnelt et al. bacteria were labelled with two fluorescent dyes prior to the peptide screen, this allowed for the recognition of 3 different peptide classes, peptides that had no effect on the bacteria, those able to lyse bacteria and those able to bind but not lyse bacteria. Validation studies found that over $50 \%$ of the peptides that were able to lyse the bacteria in the initial screen were able to inhibit bacterial growth in standard bacterial growth inhibition assays. Diehnelt et al. used these results to create a hybrid peptide formed by conjugating a peptide which showed selective binding to $S$. aureus, and a peptide with antimicrobial activity towards $S$. aureus, this conjugation was found to increase the activity of the peptides and decrease their toxicity [103].

\section{Biological synthesized peptide libraries}

\subsection{Peptide display}

Peptide display is a method where large libraries of DNA encoded peptides are screened to identify peptides with desirable properties. The peptides are maintained in association with the genes encoding them which allows for the amino acid sequence of the "hits" to be determined by gene sequencing technology. Multiple rounds of selection during the screening procedure leads to increasingly optimal peptides being isolated, a process analogous to selection of optimal mutants in nature[104]. Because these techniques often rely upon biological processes the chemical diversity is generally limited to the 20 naturally occurring amino acids [105]. Several methods of peptide display have been developed for various biological applications but phage display is by far the most prevalent [106].

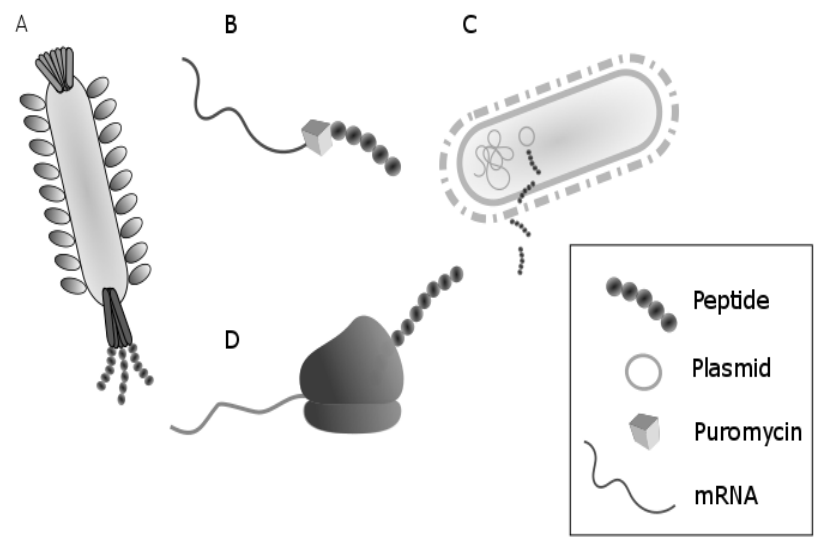

Figure 6. Different biological screening techniques that can be used in the identification of antimicrobial peptides (not to scale) A. Phage particles contain the candidate peptide attached as a fusion protein on the outer surface of the phage. B. 'mRNA display' where candidate peptides are linked to the coding mRNA by a puromycin linker. C. Transformed E.coli with 'leaky' membranes express candidate peptides. D. 'Ribosome display' the peptides are displayed in a combination with the ribosome and the mRNA still attached.

\subsection{Phage display}

Saturation mutagenesis using solid phase synthesis is the method of choice for synthesising oligomeric DNA for library construction [107]. To introduce variability to the oligonucleotides equimolar concentrations of all four activated nucleotides can be used in the successive coupling steps. However to reduce the formation of stop codons that would result in truncated peptide or uninfective virions [107] each codon can be replaced with a NNK triplet, where "N" can be A, T, G or C and "K" can be G or T. The advantage of using the NNK codon is that it only encodes one stop codon as opposed to the three permeations that would occur if NNN were used [104]. Furthermore it reduces the standard genetic code from 64 to 32 codons which reduces bias for particular amino acids, yet still encodes each of the standard 20 amino acids [104]. Other methods that can be used for generating mutated oligonucleotides include PCR based approaches and in vitro chemical mutagenesis, a thorough explanation of these strategies can be found in [108]. Following construction of the mutated oligonucleotide library, the foreign DNA is ligated to a phage gene encoding either major or minor coat proteins and the vector transformed into the phage by electroporation [107].

The combinatorial peptide libraries are thus expressed as fusion proteins attached to the surface coat of a bacteriophage. These libraries can consist of a complexity 
that allows for every possible sequence of a 7 mer peptide to be displayed[109].

Identification of best peptide candidates revolves around the process of biopanning in which the phage (containing fused peptide on the surface of their protein coat) are presented to the bacteria, allowed time to bind and then washed several times with buffer to remove unbound phage. Only phage displaying peptides that are able to bind to the target cells remain, these bound phage are then eluted and amplified by infection in suitable host bacteria. The amplification in the infected host can result in replication of 1000 viral particles per hour and due to the non lytic life cycle of filamentous phage the host cells are able to proliferate [110]. Repeated rounds of biopanning are conducted with increasing stringency. After several rounds the proportion of bound phage greatly increases[107] and these can then be amplified for genomic analysis to identify the peptide sequence.

There are some drawbacks of phage display in the search for antimicrobial peptides for example the use of fusion as opposed to monomeric peptides, the fact that phage display has currently been restricted to gene encoded amino acids and that the screen is only able to identify peptides with high binding affinity as opposed to antimicrobial activity. However despite these limitations the use of vast peptide libraries is appealing and has led to some promising results for the identification of very selective peptides.

Using the method of phage display a library of 12 mer peptides was screened for their ability to bind the membrane of E. coli. In order to identify narrow spectrum AMP's a subtractive screen was first carried out against S. aureus, whereby peptides that showed affinity for this organism were removed. Following this, six rounds of biopanning against $E$.coli were carried out with the genes of the final bound peptides sequenced. One of these peptides was subsequently synthesised and MIC's determined against a range of organisms. Despite the fact that the phage display method does not screen for peptides that are necessarily antimicrobial and instead only identifies those that bind to the bacterial membrane, the peptide discovered showed a very reasonable MIC of $8 \mu \mathrm{g} / \mathrm{ml}$. Furthermore, due to the initial subtractive screen the peptide showed no activity towards $S$. aureus, and also no activity towards Staphylococcus epidermidis, Bacillus cereus or Klebsiella pneumonia. The only other tested bacteria which the peptide showed activity towards was Pseudomonas aeruginosa. The selectivity of the peptide was also demonstrated by the fact that it showed no haemolytic activity when tested at a concentration of $500 \mu \mathrm{g} / \mathrm{ml}[33]$.

A 15-mer phage peptide library was screened against Campylobacter jejuni, an important zoonotic pathogen that is commensal in broilers but causes acute enteritis in humans [111]. Prior to the affinity screen the library was subtracted twice against another Campylobacter strain to reduce the amount of peptides with low affinity binding and a high propagation rate [107]. Following the first affinity screen the remaining library was split into two and different washing buffers were subsequently used for selecting the phage, one of which contained a detergent (Tween-20). Following three rounds of biopanning the remaining bound peptides were identified revealing a range of different sequences. It was hypothesised that this wide sequence variability was due to the double subtractive step that led to the peptides binding to a range of different epitopes. Furthermore, the group of phage that were washed using the buffer containing Tween displayed different physical characteristics to those isolated in the absence of detergent, confirming that the choice of washing buffer is an important parameter affecting the final result. Antimicrobial assays carried out on the peptides identified in the screen showed them to be far less potent when separated from the phage. The antimicrobial activity was however maintained when the peptides were tested still attached to the phage in its denatured form. This exemplifies one of the drawbacks of the phage display method, as the peptides may behave differently when removed from the phage coat. Although it has been suggested that the phage itself could be used as a delivery vehicle [112]. In a separate study three rounds of biopanning against a 10 mer phage library was carried out against $E$. coli and several peptides were identified with moderate activity in their monomeric form (12\% survival at $125 \mathrm{ug} / \mathrm{ml})$. The level of activity however was significantly improved by a single amino acid substitution and synthesising the peptides in dendrimeric tetrabranched form [113].

As phage display is an effective method for finding peptides with high affinity binding to target bacteria it has also been used to identify peptide-phage-antibiotic complexes that can selectively deliver antibiotics to pathogenic cells[114]. This approach may mean drugs previously shelved due to lack of selectivity or high toxicity may yet have therapeutic potential.

\subsection{Peptide expressions in transformed $E$. coli}

Screening of peptides may become more efficient if nonrandom libraries are utilised. Guralp et al [115] explored the use of a non-random, in silico designed library of peptides based around substituting the $\mathrm{C}$-terminal region of the bacteriocin Pln-423 with different classes of amino acids. The procedure maintained the biological synthesis strategy as opposed to SPPS peptide synthesis as it allows for the generation of larger libraries. Peptides designed in silico were reverse translated into oligonucleotides which were synthesised onto glass slides using phosphoramidite chemistry and maskless photolithography. Oligonucleotides were then amplified by emulsion PCR and expressed in the periplasmic space of E. coli with leaky outer membranes. The transformed bacteria were then overlaid with the target strain and zones of inhibition were used to identify peptides with antimicrobial activity.

Tominaga et al [116] used NNK oligonucleotides to create a library in which all the 44 amino acid positions of the bacteriocin pediocin PA-1 were substituted with different amino acids. The aim of the research was to identify the functional importance of each residue within the peptide. The DNA library was transformed into leaky E. coli cells and antimicrobial activity towards $P$. pentosaceus was 
determined by overlaying the clones with target bacteria. The study identified eight essential residues which if replaced resulted in a loss of activity, and 7 variable residues which could be replaced and antimicrobial activity maintained. Multiple sequence alignment with other pediocin-like bacteriocins showed that 7 of the 8 essential residues were conserved among this class of peptides.

There is one major advantage this method has over phage display and that is that it's directly screening for peptides with antimicrobial activity, as opposed to merely identifying peptides with high binding affinity. However, the reliance of the method on peptide diffusion to create zones of inhibition has limitation as peptides that do not diffuse effectively may produce smaller zones even if they are more antimicrobial. Furthermore there is a risk of false positives occurring due to clone to clone variation in peptide expression.

\subsection{Ribosome display}

In the aforementioned techniques a microbial host is required to express or amplify the peptide library. In the search for antimicrobial peptides this step is troublesome as there is the risk that the most potent antimicrobial peptides will simply kill the host bacteria [117]. An approach that overcomes this problem is the use of a cell free display system, such as the ribosome display methodology utilised by Xie et al [117]. In ribosome display a random DNA library is generated and its transcription and translation both take place in vitro. To form a stable peptide-ribosomemRNA complex (PRM), the mRNA contains a terminator sequence that forms a hairpin structure upon completion of translational elongation, the complex is further stabilised by reducing the temperature or introduction of chloramphenicol [118]. Xie et al. screened a peptide library against bacterial and mammalian model membranes immobilised on magnetic beads. The membranes with attached PRM complexes could then be recovered with magnets and the mRNA from the complexes bound to the membrane eluted, purified and amplified by PCR for the next round of screening. Following 5 rounds of screening 50 clones were sequenced and data analysis revealed several motifs were frequently occurring in these sequences with the most common being ALR and RVG, this suggests these motifs may facilitate membrane interactions.

\section{5. $m R N A$ display}

Another cell free peptide display technique that has been used in the search for novel antimicrobials is mRNA display. This technology involves the use of a DNA library transcribed into mRNA followed by ligation with a 3' puromycin moiety. Puromycin is a translational inhibitor antibiotic that forms a covalent bond with the peptide upon entering the A site of the ribosome and concurrently causes the peptide-mRNA fusion to be released. This complex is purified and followed by reverse translation of the mRNA, adding the cDNA construct to the complex for identification later [123].
As with other peptide display methods several selection rounds are undertaken against an immobilised target where the best hits are eluted and amplified at the end of each round. The best candidates after several selection rounds are sequenced for analysis. The complexity of mRNA libraries can be up to $10^{13}$ peptides [124] making it the most vast library discussed here. Furthermore the mRNA display complex can withstand harsher chemical treatments than ribosome display, a feature that can be useful during stringent selection steps [123]. As all steps of mRNA display are carried out in vitro they are more amenable to chemical modifications than methods requiring biological expression. To expand the chemical diversity of the peptide library Li et al [105]conjugated a penicillin moiety to $10^{12}$ unique peptide sequences. These were then screened against $\mathrm{PBP} 2 \mathrm{a}$, the penicillin binding protein surrogate for PBP2 found in methicillin resistant Staphylococcus aureus. PBP's facilitate cell wall cross linking but in the presence of $\beta$ lactam antibiotics the PBP gets acetylated inhibiting its function. Microbial resistance to $\beta$-lactams is conferred by both the slow rate of acetylation of PBP2a and its lack of high affinity for the $\beta$-lactam [125], thus finding ways of improving the affinity of $\beta$-lactams to PBP2a could be of great value. After 9 cycles of enrichment and amplification Li et al successfully used the library to isolate peptidepenicillin conjugates that were 100 fold more active than the individual parent peptide. 
Table 2. A selection of antimicrobial peptides discovered using peptide libraries.

\begin{tabular}{|c|c|c|c|c|}
\hline Sequence & Array used & $\begin{array}{c}\text { Approximate } \\
\text { number of } \\
\text { peptides } \\
\text { screened }\end{array}$ & $\begin{array}{l}\text { MIC [calculated } \mu \mathrm{M}] \\
(\text { target organism) }\end{array}$ & Reference \\
\hline RLLFRKIRRLKR & Phage display & $1,000,000,000$ & $8 \mu \mathrm{g} / \mathrm{ml}[5 \mu \mathrm{M}]($ E.coli) & [33] \\
\hline QEKIRVRLSA-CONH ${ }_{2}$ & Phage display & $1,200,000,000$ & $\begin{array}{l}125 \mu \mathrm{g} / \mathrm{ml}(12.5 \% \\
\text { survival)(E.coli) }\end{array}$ & [113] \\
\hline VRKTTSHPPSYALLH & Phage display & $2,000,000,000$ & $1.5 \mu \mathrm{m}(\mathrm{C}$. jejuni $)$ & [112] \\
\hline KYYGNGVTCGKHSCSVNWGQAFSCSVSRLANFGEGKC & $\begin{array}{c}\text { In silico design and microbial } \\
\text { expression }\end{array}$ & 12000 & $0.037 \mu \mathrm{M}$ (L. innocua) & [115] \\
\hline RWRRHKHFKRPHRKHKRGSC & Peptide microarray & 10,000 & $28 \mu \mathrm{M}($ (S. aureus) & [103] \\
\hline WKWLKKWIK - $\mathrm{CONH}_{2}$ & SPOT synthesis & 282 & $1.1 \mu \mathrm{M}$ (M. tuberculosis) & [88] \\
\hline VRLRIRVRVIRK - $\mathrm{CONH}_{2}$ & SPOT synthesis & 228 & $\begin{array}{c}3 \mu \mathrm{g} / \mathrm{ml}[2 \mu \mathrm{M}](P . \\
\text { aeruginosa })\end{array}$ & [86] \\
\hline KRWWKWWRR-CONH ${ }_{2}$ & $\begin{array}{l}\text { In silico prediction and SPOT } \\
\text { synthesis }\end{array}$ & $\begin{array}{c}100,000 \text { screened } \\
\text { in silico, } 200 \\
\text { tested on using } \\
\text { SPOT synthesis } \\
\end{array}$ & $0.7 \mu \mathrm{M}($ P.aeruginosa $)$ & [91] \\
\hline Ac-RRWCKR-CONH ${ }_{2}$ & Split and mix & 160,000 & $\begin{array}{c}67-130 \mu \mathrm{g} / \mathrm{ml}[70- \\
140 \mu \mathrm{M}](\text { C.albicans })\end{array}$ & [50] \\
\hline WGWRDIVRAIRKVAAPVLST & Tea bag & 20 & $\begin{array}{c}25 \mu \mathrm{M}(\text { E.coli, } \\
\text { V.alginolitycus, } V . \\
\text { ordalli) }\end{array}$ & [76] \\
\hline VGATWSKVIRGPGKSKPNWS & Multi-pin & 53 & $\begin{array}{c}11 \mu \mathrm{g} / \mathrm{ml}[5 \mu \mathrm{M}](\text { E.coli }) \\
10.6 \mu \mathrm{g} / \mathrm{ml}[5 \mu \mathrm{M}] \\
(\text { S.aureus })\end{array}$ & [79] \\
\hline RRWVRRVRRWVRRVVRVVRRWVRR & Small peptide library & 12 & $\begin{array}{l}0.3 \mu \mathrm{M} \text { (S aurues, } \\
\text { P.aeruginosa) }\end{array}$ & [119] \\
\hline KWKSFLKTFKSAKKTLLHTALKAISS & Small peptide library & 7 & $\begin{array}{c}2 \mu \mathrm{g} / \mathrm{ml}[1 \mu \mathrm{M}](P . \\
\text { aeruginosa })\end{array}$ & [120] \\
\hline KWKSFIKKLTKKFLHSAKKF & Small peptide library & 23 & $\begin{array}{c}0.5 \text { to } 8 \mu \mathrm{g} / \mathrm{ml}[0.2-3 \mu \mathrm{M}] \\
\text { Broad Spectrum } \\
\text { (ESKAPE) }\end{array}$ & [121] \\
\hline RRRWWWF-CONH $_{2}$ & Small peptide library & 16 & $\begin{array}{l}4-8 \mu \mathrm{g} / \mathrm{ml}(3.3-6.7 \mu \mathrm{M}) \\
\text { (Streptococcus mutans) }\end{array}$ & [122] \\
\hline
\end{tabular}




\section{Small peptide libraries}

For the purpose of this review small peptide libraries will consist of no more than 50 peptides. The small peptide library approach will almost exclusively follow a rational design of peptides of interest rather than a random approach. One of the easiest and most established ways to generate small peptide libraries is to take an existing peptide and modify it, which is mainly done through substitution of amino acids into each position of the peptide (if short enough in length) or at a particular position within the peptide.

Such a library was created by Tan $e t$ al, where six amino acids (Alanine, Glycine, Glutamine, Leucine, Lysine, and Serine) were all individually substituted into the $16^{\text {th }}$ position of the parent antimicrobial peptide known as V13K [120]. They found that the more hydrophobic the amino acid substitution the more antimicrobial the peptide; however at the same time these peptides also exhibited the highest toxicity towards red blood cells.

Mishra et al designed a library, by taking the first $8 \mathrm{~N}$ terminal residues from a well-studied antimicrobial peptide Lactoferrin. L1 (APRKNVRW) served as a template to create a further 9 variants. Initial screening against $E$. coli reported L10 (WFRKQLKW) having an MIC of $1 \mu \mathrm{g} / \mathrm{ml}$. L10 was further tested against 30 multidrug-resistant isolates of extended spectrum $\beta$-lactamase (ESBLs) producing bacteria, including $P$. aeruginosa, K. pneumoniae and Acinobacter species with the MICs reported to be in the range of $1-8 \mu \mathrm{g} / \mathrm{ml}$, while also having an MIC of $6.25 \mu \mathrm{g} / \mathrm{ml}$ against $C$. albicans. In addition L10 showed no hemolytic activity, even at high concentrations of $800 \mu \mathrm{g} / \mathrm{ml}[126]$.

Potent antimicrobial peptides such as tritrpticin and indolicidin are found naturally enriched in Trp residues [127],[128]; hence one approach in the field of antimicrobial peptides has been to enhance or design peptides by enriching them with tryptophan residues. The rationale behind this is that tryptophan has shown strong inclination towards lipid bilayers[129]. In keeping with this rationale, Deslouches et al designed a small antimicrobial peptide library exclusively consisting of peptides of different lengths containing just tryptophan and arginine. This resulted in the creation of a library of WR peptides ranging from 6 to 18 amino acids in length, with the most active peptide in their library being WR12, which showed activity against a wide range of MDR and XDR pathogens, including A. baumannii, $P$. aeruginosa and MRSA with MICs ranging between 4 and $11 \mu \mathrm{g} / \mathrm{ml}$. However it only showed weak activity against $K$. pneumonia with an MIC of $27 \mu \mathrm{g} / \mathrm{ml}$ [130]. Furthermore Deslouches et al later tested peptide WR12 against the ESKAPE pathogens, as well as 100 clinical isolates. WR12 was reported to be active against these pathogens at concentrations $\leq 10 \mu \mathrm{M}$ [131].
Jin-Jiang et al designed a peptide CP-P (KWKSFIKKLTSKFLHLAKKF-NH ${ }_{2}$ ) by splicing the sequences of peptides CP26 (KWKSFIKKLTSAAKKVVTTAKPLISS-NH ${ }_{2}$ ) and P18 (KWKLFKKIPKFLHLAKKF-NH $\mathrm{N}_{2}$ ). The reasoning behind using CP26 and P18 as a basis for their design was due to these 2 peptides reportedly having strong antimicrobial activity. Furthermore they made a serine substitution on the $16^{\text {th }}$ position of CP-P, which resulted in a 75\% improvement in the MIC $(3.125 \mu \mathrm{g} / \mathrm{ml})$ against $P$. aeruginosa, as compared the parent CP-P $(12.5 \mu \mathrm{g} / \mathrm{ml})$. Other variants were produced from the S16 parent by performing substitutions of amino acids at different positions. It was found that one of the peptides from the library with a Lys substitution at position number 11 (K11), showed a very low MIC against $P$. aeruginosa $(1.6 \mu \mathrm{g} / \mathrm{ml})$, as well as high activity towards various other gram negative and positive bacteria ( 0.5 to 8 $\mu \mathrm{g} / \mathrm{ml})$, hence exhibiting a broad spectrum activity. The peptide also demonstrated very low haemolytic activity [121].

Alanine scanning is another method to create libraries. This is prepared by individually replacing each amino acid in the peptide sequence with alanine. This enables identification of specific amino acid residues which are responsible for the activity of the peptide. Alanine is most commonly used due to it being the smallest chiral amino acid, however other amino acid scans can also be performed. McClean et al. used a soybean derived peptide as a starting point and carried out an alanine scan. Interestingly the variant sequence (PGAAVFK) showed an improved activity, with MICs of 12 and $36 \mu \mathrm{M}$ against $S$. aureus and C. albicans compared to the original peptide (PGTAVFK), which had MICs of 31 and $201 \mu \mathrm{M}$ respectively [132].

Alvarez-Ordonez et al. shortened a peptide, changed the amino acids sequence, performed an alanine scan, and enriched the peptide with Trp and Phe residues to determine how each can influence the activity of a peptide. They used the peptide $\alpha_{\mathrm{s} 2}$-casein $\mathrm{f}(183-207)$, which is a fragment of a milk derived peptide, $\alpha_{\mathrm{s} 2}$-casein. They found that removing the last 5 amino acids from the $\mathrm{C}$-terminal caused a decrease in activity against the test pathogens Listeria. monocytogenes and Cronobacter sakazakii. Furthermore a variant $\alpha_{\mathrm{s} 2}$-casein $\mathrm{f}(183-207) \mathrm{V} 19$ which had arginine replaced in the $23^{\text {rd }}$ position with an alanine caused a large decrease in activity against the test bacteria, as did replacement of other positively charged amino acids, indicating the importance of arginine and positive charge in the activity of this peptide. On the other hand, replacement of proline at positions 14 and 20 increased the potency. In addition enrichment of the peptide with Trp and Phe residues resulted in increased potency towards $L$. monocytogenes, however displayed no such effect against C. sakazakii [133]. 


\section{Conclusion}

Whilst the number of antimicrobials entering the market is stagnating the levels of antimicrobial resistance seen amongst pathogens is rising. This means the search for effective and novel antimicrobials is both urgent and imperative. Antimicrobial peptides have the potential to curtail the problem, however with so many possible variations of the molecules identifying optimised candidates is challenging.

Peptides libraries offer a solution to this, and we have discussed several different approaches that can be utilised in both the creation and the screening of the library. These different strategies each have their advantages and disadvantages but generally speaking the choice is between large libraries that have moderate predictive power towards finding an optimised peptide and smaller libraries with a more robust predictive power.

Peptide libraries have already been used to find many peptides that have promising therapeutic potential and through strategies such as substituting amino acids into different positions within the peptide, along with bioinformatical analysis of large libraries a greater understanding of antimicrobial peptides can be achieved.

\section{References}

[1] Tadesse, D. A.; Zhao, S.; Tong, E.; Ayers, S.; Singh, A.; Bartholomew, M. J.; McDermott, P. F. Antimicrobial Drug Resistance in Escherichia Coli from Humans and Food Animals, United States, 1950-2002. Emerging Infectious Diseases, 2012, $18,741-749$.

[2] Kirby, W. M.; Rantz, L. A. QUANTITATIVE STUDIES OF SULFONAMIDE RESISTANCE. $J$. Exp. Med. 1943, 77 (1), 29-39.

[3] Grundmann, H.; Klugman, K. P.; Walsh, T.; Ramon-Pardo, P.; Sigauque, B.; Khan, W.; Laxminarayan, R.; Heddini, A.; Stelling, J. A Framework for Global Surveillance of Antibiotic Resistance. Drug Resist. Updat. 2011, 14 (2), 79 87.

[4] Arnold, S. R.; Straus, S. E. Interventions to Improve Antibiotic Prescribing Practices in Ambulatory Care. Cochrane database Syst. Rev. 2005, No. 4, CD003539.

[5] Pechère, J. C. Patients' Interviews and Misuse of Antibiotics. Clin. Infect. Dis. 2001, 33 Suppl 3 (Supplement_3), S170-S173.

[6] Cantas, L.; Shah, S. Q. A.; Cavaco, L. M.; Manaia, C. M.; Walsh, F.; Popowska, M.; Garelick, H.; Bürgmann, H.; Sørum, H. A Brief MultiDisciplinary Review on Antimicrobial Resistance in Medicine and Its Linkage to the Global Environmental Microbiota. Front. Microbiol. 2013, 4, 96.

[7] Paramythiotou, E.; Lucet, J. Acquisition of Multidrug-Resistant Pseudomonas Aeruginosa in Patients in Intensive Care Units: Role of Antibiotics with Antipseudomonal Activity. Clin. Infect. ... 2004, 38.

[8] Matteelli, A.; Roggi, A.; Carvalho, A. C. Extensively Drug-Resistant Tuberculosis: Epidemiology and Management. Clin. Epidemiol. 2014, 6, 111-118.

[9] Velayati, A. A.; Masjedi, M. R.; Farnia, P.; Tabarsi, P.; Ghanavi, J.; Ziazarifi, A. H.; Hoffner, S. E. Emergence of New Forms of Totally DrugResistant Tuberculosis Bacilli: Super Extensively Drug-Resistant Tuberculosis or Totally DrugResistant Strains in Iran. Chest 2009, 136 (2), 420 425 .

[10] Boucher, H. W.; Talbot, G. H.; Bradley, J. S.; Edwards, J. E.; Gilbert, D.; Rice, L. B.; Scheld, M.; Spellberg, B.; Bartlett, J. Bad Bugs, No Drugs: 
No ESKAPE! An Update from the Infectious Diseases Society of America. Clin. Infect. Dis. 2009, 48 (1), 1-12.

[11] Bahar, A. A.; Ren, D. Antimicrobial Peptides. Pharmaceuticals (Basel). 2013, 6 (12), 1543-1575.

[12] FDA approved drugs for infections and infectious diseases http://www.centerwatch.com/druginformation/fda-approved-drugs/therapeuticarea/25/infections-and-infectious-diseases.

[13] Dalovisio, J. R. IDSA: Infancy to Adulthood in Four Decades. Clin. Infect. Dis. 2005, 40 (4), 574578 .

[14] Yin, L. M.; Edwards, M. A.; Li, J.; Yip, C. M.; Deber, C. M. Roles of Hydrophobicity and Charge Distribution of Cationic Antimicrobial Peptides in Peptide-Membrane Interactions. J. Biol. Chem. 2012, 287 (10), 7738-7745.

[15] Mania, D.; Hilpert, K.; Ruden, S.; Fischer, R.; Takeshita, N. Screening for Antifungal Peptides and Their Modes of Action in Aspergillus Nidulans. Appl. Environ. Microbiol. 2010, 76 (21), 7102-7108.

[16] Gordon, Y. J.; Romanowski, E. G.; McDermott, A. M. A Review of Antimicrobial Peptides and Their Therapeutic Potential as Anti-Infective Drugs. Curr. Eye Res. 2005, 30 (7), 505-515.

[17] Boulanger, N.; Lowenberger, C.; Volf, P.; Ursic, R.; Sigutova, L.; Sabatier, L.; Svobodova, M.; Beverley, S. M.; Späth, G.; Brun, R.; Pesson, B.; Bulet, P. Characterization of a Defensin from the Sand Fly Phlebotomus Duboscqi Induced by Challenge with Bacteria or the Protozoan Parasite Leishmania Major. Infect. Immun. 2004, 72 (12), 7140-7146.

[18] Cai, Y.; Chai, D.; Wang, R.; Liang, B.; Bai, N. Colistin Resistance of Acinetobacter Baumannii: Clinical Reports, Mechanisms and Antimicrobial Strategies. J. Antimicrob. Chemother. 2012, 67 (7), 1607-1615.

[19] Saravolatz, L. D.; Pawlak, J.; Johnson, L.; Bonilla, H.; Fakih, M. G.; Fugelli, A.; Olsen, W. M. In Vitro Activities of LTX-109, a Synthetic Antimicrobial Peptide, against MethicillinResistant, Vancomycin-Intermediate, VancomycinResistant, Daptomycin-Nonsusceptible, and Linezolid-Nonsusceptible Staphylococcus Aureus. Antimicrob. Agents Chemother. 2012, 56 (8), 4478-4482.
[20] Uccelletti, D.; Zanni, E.; Marcellini, L.; Palleschi, C.; Barra, D.; Mangoni, M. L. Anti-Pseudomonas Activity of Frog Skin Antimicrobial Peptides in a Caenorhabditis Elegans Infection Model: A Plausible Mode of Action in Vitro and in Vivo. Antimicrob. Agents Chemother. 2010, 54 (9), 3853-3860.

[21] Myhrman, E.; Håkansson, J.; Lindgren, K.; Björn, C.; Sjöstrand, V.; Mahlapuu, M. The Novel Antimicrobial Peptide PXL150 in the Local Treatment of Skin and Soft Tissue Infections. Appl. Microbiol. Biotechnol. 2013, 97 (7), 3085-3096.

Hurdle, J. G.; O’Neill, A. J.; Chopra, I.; Lee, R. E. Targeting Bacterial Membrane Function: An Underexploited Mechanism for Treating Persistent Infections. Nat. Rev. Microbiol. 2011, 9 (1), 62-75.

[23] Tjabringa, G. S.; Ninaber, D. K.; Drijfhout, J. W.; Rabe, K. F.; Hiemstra, P. S. Human Cathelicidin LL-37 Is a Chemoattractant for Eosinophils and Neutrophils That Acts via Formyl-Peptide Receptors. Int. Arch. Allergy Immunol. 2006, 140 (2), 103-112.

Choi, K.-Y.; Chow, L. N. Y.; Mookherjee, N. Cationic Host Defence Peptides: Multifaceted Role in Immune Modulation and Inflammation. $J$. Innate Immun. 2012, 4 (4), 361-370.

[25] Steinstraesser, L.; Koehler, T.; Jacobsen, F.; Daigeler, A.; Goertz, O.; Langer, S.; Kesting, M.; Steinau, H.; Eriksson, E.; Hirsch, T. Host Defense Peptides in Wound Healing. Mol. Med. 14 (7-8), 528-537.

[26] Hartmann, M.; Berditsch, M.; Hawecker, J.; Ardakani, M. F.; Gerthsen, D.; Ulrich, A. S. Damage of the Bacterial Cell Envelope by Antimicrobial Peptides Gramicidin S and PGLa as Revealed by Transmission and Scanning Electron Microscopy. Antimicrob. Agents Chemother. 2010, 54 (8), 3132-3142.

[27] Yount, N. Y.; Yeaman, M. R. Peptide Antimicrobials: Cell Wall as a Bacterial Target. Ann. N. Y. Acad. Sci. 2013, 1277 (1), 127-138.

[28] Laughlin, T. F.; Ahmad, Z. Inhibition of Escherichia Coli ATP Synthase by Amphibian Antimicrobial Peptides. Int. J. Biol. Macromol. 2010, 46 (3), 367-374.

[29] Von Deuster, C. I. E.; Knecht, V. Antimicrobial Selectivity Based on Zwitterionic Lipids and Underlying Balance of Interactions. Biochim. Biophys. Acta 2012, 1818 (9), 2192-2201. 
[30] Wang, G.; Li, X.; Wang, Z. APD2: The Updated Antimicrobial Peptide Database and Its Application in Peptide Design. Nucleic Acids Res. 2009, 37 (Database issue), D933-D937.

[31] Epand, R. F.; Pollard, J. E.; Wright, J. O.; Savage, P. B.; Epand, R. M. Depolarization, Bacterial Membrane Composition, and the Antimicrobial Action of Ceragenins. Antimicrob. Agents Chemother. 2010, 54 (9), 3708-3713.

[32] Friedrich, C. L.; Moyles, D.; Beveridge, T. J.; Hancock, R. E. W. Antibacterial Action of Structurally Diverse Cationic Peptides on GramPositive Bacteria. Antimicrob. Agents Chemother. 2000, 44 (8), 2086-2092.

[33] Sainath Rao, S.; Mohan, K. V. K.; Atreya, C. D. A Peptide Derived from Phage Display Library Exhibits Antibacterial Activity against E. Coli and Pseudomonas Aeruginosa. PLoS One 2013, 8 (2), e56081.

[34] Yeaman, M.; Yount, N. Mechanisms of Antimicrobial Peptide Action and Resistance. Pharmacol. Rev. 2003, 55 (1), 27-55.

[35] Brogden, K. A. Antimicrobial Peptides: Pore Formers or Metabolic Inhibitors in Bacteria? Nat. Rev. Microbiol. 2005, 3 (3), 238-250.

[36] Subbalakshmi, C.; Sitaram, N. Mechanism of Antimicrobial Action of Indolicidin. FEMS Microbiol. Lett. 1998, 160 (1), 91-96.

[37] Park, C. B.; Kim, H. S.; Kim, S. C. Mechanism of Action of the Antimicrobial Peptide Buforin II: Buforin II Kills Microorganisms by Penetrating the Cell Membrane and Inhibiting Cellular Functions. Biochem. Biophys. Res. Commun. 1998, 244 (1), 253-257.

[38] Andreu, D.; Rivas, L. Animal Antimicrobial Peptides: An Overview. Biopolymers 1998, 47 (6), 415-433.

[39] Koch, D. C.; Schmidt, T. H.; Sahl, H.-G.; Kubitscheck, U.; Kandt, C. Structural Dynamics of the Cell Wall Precursor Lipid II in the Presence and Absence of the Lantibiotic Nisin. Biochim. Biophys. Acta - Biomembr. 2014, 1838 (12), 30613068.

[40] Wang, C.-W.; Yip, B.-S.; Cheng, H.-T.; Wang, A.H.; Chen, H.-L.; Cheng, J.-W.; Lo, H.-J. Increased Potency of a Novel D-Beta-NaphthylalanineSubstituted Antimicrobial Peptide against Fluconazole-Resistant Fungal Pathogens. FEMS Yeast Res. 2009, 9 (6), 967-970.
[41] Lai, Y.; Villaruz, A. E.; Li, M.; Cha, D. J.; Sturdevant, D. E.; Otto, M. The Human Anionic Antimicrobial Peptide Dermcidin Induces Proteolytic Defence Mechanisms in Staphylococci. Mol. Microbiol. 2007, 63 (2), 497-506.

Li, C.; Salditt, T. Structure of Magainin and Alamethicin in Model Membranes Studied by XRay Reflectivity. Biophys. J. 2006, 91 (9), 32853300 .

[43] Dunsche, A.; Acil, Y.; Dommisch, H.; Siebert, R.; Schroder, J.-M.; Jepsen, S. The Novel Human Beta-Defensin-3 Is Widely Expressed in Oral Tissues. Eur. J. Oral Sci. 2002, 110 (2), 121-124.

[44] De Smet, K.; Contreras, R. Human Antimicrobial Peptides: Defensins, Cathelicidins and Histatins. Biotechnol. Lett. 2005, 27 (18), 1337-1347.

[45] Yeaman, M. R.; Yount, N. Y. Unifying Themes in Host Defence Effector Polypeptides. Nat. Rev. Microbiol. 2007, 5 (9), 727-740.

[46] Merrifield, R. B. Solid Phase Peptide Synthesis. I. The Synthesis of a Tetrapeptide. J. Am. Chem. Soc. 1963, 85 (14), 2149-2154.

[47] Miertus, S.; Fassina, G. Combinatorial Chemistry \& Technoigies Methods \& Applications, 2nd ed.; CRC Press, 2005.

[48] Miertus, S.; Fassina, G.; Seneci, P. CONCEPTS OF COMBINATORIAL CHEMISTRY AND COMBINATORIAL TECHNOLOGIES. 2000, 94, 1104-1110.

[49] Blondelle, S. E.; Takahashi, E.; Weber, P. A.; Houghten, R. A. Identification of Antimicrobial Peptides by Using Combinatorial Libraries Made up of Unnatural Amino Acids. Antimicrob. Agents Chemother. 1994, 38 (10), 2280-2286.

[50] Blondelle, S. E.; Takahashi, E.; Dinh, K. T.; Houghten, R. A. The Antimicrobial Activity of Hexapeptides Derived from Synthetic Combinatorial Libraries. J. Appl. Bacteriol. 1995, 78 (1), 39-46.

[51] Simmaco, M.; Mignogna, G.; Canofeni, S.; Miele, R.; Mangoni, M. L.; Barra, D. Temporins, Antimicrobial Peptides from the European Red Frog Rana Temporaria. Eur. J. Biochem. 1996, 242 (3), 788-792.

[52] Romeo, D.; Skerlavaj, B.; Bolognesi, M.; Gennaro, R. Structure and Bactericidal Activity of an Antibiotic Dodecapeptide Purified from Bovine 
Neutrophils. J. Biol. Chem. 1988, 263 (20), 95739575.

[53] Monincová, L.; Budesínský, M.; Slaninová, J.; Hovorka, O.; Cvacka, J.; Voburka, Z.; Fucík, V.; Borovicková, L.; Bednárová, L.; Straka, J.; Cerovský, V. Novel Antimicrobial Peptides from the Venom of the Eusocial Bee Halictus Sexcinctus (Hymenoptera: Halictidae) and Their Analogs.

Amino Acids 2010, 39 (3), 763-775.

[54] Townsley, L. E.; Tucker, W. A.; Sham, S.; Hinton, J. F. Structures of Gramicidins A, B, and C Incorporated into Sodium Dodecyl Sulfate Micelles. Biochemistry 2001, 40 (39), 1167611686.

[55] Muta, T.; Fujimoto, T.; Nakajima, H.; Iwanaga, S. Tachyplesins Isolated from Hemocytes of Southeast Asian Horseshoe Crabs (Carcinoscorpius Rotundicauda and Tachypleus Gigas):

Identification of a New Tachyplesin, Tachyplesin III, and a Processing Intermediate of Its Precursor. J. Biochem. 1990, 108 (2), 261-266.

[56] Hayashi, F.; Nagashima, K.; Terui, Y.; Kawamura, Y.; Matsumoto, K.; Itazaki, H. The Structure of PA48009: The Revised Structure of Duramycin. $J$. Antibiot. (Tokyo). 1990, 43 (11), 1421-1430.

[57] Zhang, S.; Guo, H.; Shi, F.; Wang, H.; Li, L.; Jiao, X.; Wang, Y.; Yu, H. Hainanenins: A Novel Family of Antimicrobial Peptides with Strong Activity from Hainan Cascade-Frog, Amolops Hainanensis. Peptides 2012, 33 (2), 251-257.

[58] Kim, P. Il; Sohng, J. K.; Sung, C.; Joo, H.-S.; Kim, E.-M.; Yamaguchi, T.; Park, D.; Kim, B.-G.

Characterization and Structure Identification of an Antimicrobial Peptide, Hominicin, Produced by Staphylococcus Hominis MBBL 2-9. Biochem. Biophys. Res. Commun. 2010, 399 (2), 133-138.

[59] Selsted, M. E.; Harwig, S. S.; Ganz, T.; Schilling, J. W.; Lehrer, R. I. Primary Structures of Three Human Neutrophil Defensins. J. Clin. Invest. 1985, 76 (4), 1436-1439.

[60] Thompson, S. A.; Tachibana, K.; Nakanishi, K.; Kubota, I. Melittin-Like Peptides from the SharkRepelling Defense Secretion of the Sole Pardachirus Pavoninus. Science 1986, 233 (4761), 341-343.

[61] Rogers, L. A. THE INHIBITING EFFECT OF STREPTOCOCCUS LACTIS ON LACTOBACILLUS BULGARICUS. J. Bacteriol. 1928, 16 (5), 321-325.
[62] Bensch, K. W.; Raida, M.; Mägert, H. J.; SchulzKnappe, P.; Forssmann, W. G. hBD-1: A Novel Beta-Defensin from Human Plasma. FEBS Lett. 1995, 368 (2), 331-335.

[63] Agerberth, B.; Gunne, H.; Odeberg, J.; Kogner, P.; Boman, H. G.; Gudmundsson, G. H. FALL-39, a Putative Human Peptide Antibiotic, Is CysteineFree and Expressed in Bone Marrow and Testis. Proc. Natl. Acad. Sci. U. S. A. 1995, 92 (1), 195199.

[64] Park, C. B.; Kim, M. S.; Kim, S. C. A Novel Antimicrobial Peptide from Bufo Bufo Gargarizans. Biochem. Biophys. Res. Commun. 1996, 218 (1), 408-413.

[65] Cerovský, V.; Zdárek, J.; Fucík, V.; Monincová, L.; Voburka, Z.; Bém, R. Lucifensin, the LongSought Antimicrobial Factor of Medicinal Maggots of the Blowfly Lucilia Sericata. Cell. Mol. Life Sci. 2010, 67 (3), 455-466.

[66] Rausch, J. M.; Marks, J. R.; Wimley, W. C. Rational Combinatorial Design of Pore-Forming Beta-Sheet Peptides. Proc. Natl. Acad. Sci. U. S. A. 2005, 102 (30), 10511-10515.

Wimley, W. C. The Versatile Beta-Barrel Membrane Protein. Curr. Opin. Struct. Biol. 2003, 13 (4), 404-411.

[68] Wimley, W. C. Toward Genomic Identification of Beta-Barrel Membrane Proteins: Composition and Architecture of Known Structures. Protein Sci. 2002, 11 (2), 301-312.

[69] Rathinakumar, R.; Wimley, W. C. Biomolecular Engineering by Combinatorial Design and HighThroughput Screening: Small, Soluble Peptides That Permeabilize Membranes. J. Am. Chem. Soc. 2008, 130 (30), 9849-9858.

[70] Rausch, J. M.; Marks, J. R.; Rathinakumar, R.; Wimley, W. C. B-Sheet Pore-Forming Peptides Selected from a Rational Combinatorial Library: Mechanism of Pore Formation in Lipid Vesicles and Activity in Biological Membranes $\dagger$. Biochemistry 2007, 46 (43), 12124-12139.

[71] Krauson, A. J.; He, J.; Wimley, A. W.; Hoffmann, A. R.; Wimley, W. C. Synthetic Molecular Evolution of Pore-Forming Peptides by Iterative Combinatorial Library Screening. ACS Chem. Biol. 2013, 8 (4), 823-831.
Geysen, H. M.; Meloen, R. H.; Barteling, S. J. Use of Peptide Synthesis to Probe Viral Antigens for Epitopes to a Resolution of a Single Amino Acid. 
Proc. Natl. Acad. Sci. U. S. A. 1984, 81 (13), 3998-4002.

[73] Furka, A.; Sebestyén, F.; Asgedom, M.; Dibó, G. General Method for Rapid Synthesis of Multicomponent Peptide Mixtures. Int. J. Pept. Protein Res. 1991, 37 (6), 487-493.

[74] Houghten, R. A. General Method for the Rapid Solid-Phase Synthesis of Large Numbers of Peptides: Specificity of Antigen-Antibody Interaction at the Level of Individual Amino Acids. Proc. Natl. Acad. Sci. U. S. A. 1985, 82 (15), 5131-5135.

[75] Sällberg, M.; Rudén, U.; Magnius, L. O.; Norrby, E.; Wahren, B. Rapid “Tea-Bag” Peptide Synthesis Using 9-Fluorenylmethoxycarbonyl (Fmoc) Protected Amino Acids Applied for Antigenic Mapping of Viral Proteins. Immunol. Lett. 1991, 30 (1), 59-68.

[76] Jofré, C.; Guzmán, F.; Cárdenas, C.; Albericio, F.; Marshall, S. H. A Natural Peptide and Its Variants Derived from the Processing of Infectious Pancreatic Necrosis Virus (IPNV) Displaying Enhanced Antimicrobial Activity: A Novel Alternative for the Control of Bacterial Diseases. Peptides 2011, 32 (5), 852-858.

[77] Bray, A. M.; Joe Maeji, N.; Mario Geysen, H. The Simultaneous Multiple Production of Solution Phase Peptides; Assessment of the Geysen Method of Simultaneous Peptide Synthesis. Tetrahedron Lett. 1990, 31 (40), 5811-5814.

[78] Brogden, K. A.; Ackermann, M.; Huttner, K. M. Small, Anionic, and Charge-Neutralizing Propeptide Fragments of Zymogens Are Antimicrobial. Antimicrob. Agents Chemother. 1997, 41 (7), 1615-1617.

[79] Iwasaki, T.; Ishibashi, J.; Kubo, M.; Taylor, D.; Yamakawa, M. Multiple Functions of Short Synthetic Enantiomeric Peptides Based on Beetle Defensins. Biosci. Biotechnol. Biochem. 2009, 73 (3), 683-687.

[80] Frank, R.; Döring, R. Simultaneous Multiple Peptide Synthesis under Continuous Flow Conditions on Cellulose Paper Discs as Segmental Solid Supports. Tetrahedron 1988, 44 (19), 60316040 .

[81] Hilper, K.; Winkler, D. F. H.; Hancock, R. E. W. Cellulose-Bound Peptide Arrays: Preparation and Applications. Biotechnol. Genet. Eng. Rev. 2007, 24, 31-106.
[82] Hilpert, K.; Winkler, D. F. H.; Hancock, R. E. W. Peptide Arrays on Cellulose Support: SPOT Synthesis, a Time and Cost Efficient Method for Synthesis of Large Numbers of Peptides in a Parallel and Addressable Fashion. Nat. Protoc. 2007, 2 (6), 1333-1349.

[83] Kamradt, T.; Volkmer-Engert, R. Cross-Reactivity of T Lymphocytes in Infection and Autoimmunity. Mol. Divers. 2004, 8 (3), 271-280.

[84] Hilpert, K.; Volkmer-Engert, R.; Walter, T.; Hancock, R. E. W. High-Throughput Generation of Small Antibacterial Peptides with Improved Activity. Nat. Biotechnol. 2005, 23 (8), 10081012.

[85] Hilpert, K.; Hancock, R. E. W. Use of Luminescent Bacteria for Rapid Screening and Characterization of Short Cationic Antimicrobial Peptides Synthesized on Cellulose Using Peptide Array Technology. Nat. Protoc. 2007, 2 (7), 1652 1660.

[86] Hilpert, K.; Elliott, M. R.; Volkmer-Engert, R.; Henklein, P.; Donini, O.; Zhou, Q.; Winkler, D. F. H.; Hancock, R. E. W. Sequence Requirements and an Optimization Strategy for Short Antimicrobial Peptides. Chem. Biol. 2006, 13 (10), 1101-1107.

Cherkasov, A.; Hilpert, K.; Jenssen, H.; Fjell, C. D.; Waldbrook, M.; Mullaly, S. C.; Volkmer, R.; Hancock, R. E. W. Use of Artificial Intelligence in the Design of Small Peptide Antibiotics Effective against a Broad Spectrum of Highly AntibioticResistant Superbugs. ACS Chem. Biol. 2009, 4 (1), 65-74.

[88] Ramón-García, S.; Mikut, R.; Ng, C.; Ruden, S.; Volkmer, R.; Reischl, M.; Hilpert, K.; Thompson, C. J. Targeting Mycobacterium Tuberculosis and Other Microbial Pathogens Using Improved Synthetic Antibacterial Peptides. Antimicrob. Agents Chemother. 2013, 57 (5), 2295-2303.

[89] Hilpert, K.; Elliott, M.; Jenssen, H.; Kindrachuk, J.; Fjell, C. D.; Körner, J.; Winkler, D. F. H.; Weaver, L. L.; Henklein, P.; Ulrich, A. S.; Chiang, S. H. Y.; Farmer, S. W.; Pante, N.; Volkmer, R.; Hancock, R. E. W. Screening and Characterization of Surface-Tethered Cationic Peptides for Antimicrobial Activity. Chem. Biol. 2009, 16 (1), 58-69.

[90] Gao, G.; Lange, D.; Hilpert, K.; Kindrachuk, J.; Zou, Y.; Cheng, J. T. J.; Kazemzadeh-Narbat, M.; Yu, K.; Wang, R.; Straus, S. K.; Brooks, D. E.; Chew, B. H.; Hancock, R. E. W.; Kizhakkedathu, J. N. The Biocompatibility and Biofilm Resistance 
of Implant Coatings Based on Hydrophilic

Polymer Brushes Conjugated with Antimicrobial

Peptides. Biomaterials 2011, 32 (16), 3899-3909.

[91] Wieczorek, M.; Jenssen, H.; Kindrachuk, J.; Scott, W. R. P.; Elliott, M.; Hilpert, K.; Cheng, J. T. J.; Hancock, R. E. W.; Straus, S. K. Structural Studies of a Peptide with Immune Modulating and Direct Antimicrobial Activity. Chem. Biol. 2010, 17 (9), 970-980.

[92] Rivas-Santiago, B.; Castañeda-Delgado, J. E.; Rivas Santiago, C. E.; Waldbrook, M.; GonzálezCuriel, I.; León-Contreras, J. C.; Enciso-Moreno, J. A.; Villar, V. del; Mendez-Ramos, J.; Hancock, R. E. W.; Hernandez-Pando, R. Ability of Innate Defence Regulator Peptides IDR-1002, IDR-HH2 and IDR-1018 to Protect against Mycobacterium Tuberculosis Infections in Animal Models. PLoS One 2013, 8 (3), e59119.

[93] De la Fuente-Núñez, C.; Reffuveille, F.; Haney, E. F.; Straus, S. K.; Hancock, R. E. W. BroadSpectrum Anti-Biofilm Peptide That Targets a Cellular Stress Response. PLoS Pathog. 2014, 10 (5), e1004152.

[94] Hammami, R.; Fliss, I. Current Trends in Antimicrobial Agent Research: Chemo- and Bioinformatics Approaches. Drug Discov. Today 2010, 15 (13-14), 540-546.

[95] Fjell, C. D.; Hiss, J. A.; Hancock, R. E. W.; Schneider, G. Designing Antimicrobial Peptides: Form Follows Function. Nat. Rev. Drug Discov. 2012, 11 (1), 37-51.

[96] Torrent, M.; Nogués, M. V.; Boix, E. Discovering New in Silico Tools for Antimicrobial Peptide Prediction. Curr. Drug Targets 2012, 13 (9), 1148-1157.

[97] Cruz-Monteagudo, M.; Borges, F.; Cordeiro, M. N. D. S. Jointly Handling Potency and Toxicity of Antimicrobial Peptidomimetics by Simple Rules from Desirability Theory and Chemoinformatics. $J$. Chem. Inf. Model. 2011, 51 (12), 3060-3077.

[98] Torrent, M.; Andreu, D.; Nogués, V. M.; Boix, E. Connecting Peptide Physicochemical and Antimicrobial Properties by a Rational Prediction Model. PLoS One 2011, 6 (2), e16968.

[99] Fernandes, F. C.; Rigden, D. J.; Franco, O. L. Prediction of Antimicrobial Peptides Based on the Adaptive Neuro-Fuzzy Inference System Application. Biopolymers 2012, 98 (4), 280-287.
[100] Mikut, R. Computer-Based Analysis, Visualization, and Interpretation of Antimicrobial Peptide Activities. Methods Mol. Biol. 2010, 618, 287-299.

[101] Lata, S.; Sharma, B.; Raghava, G. Analysis and Prediction of Antibacterial Peptides. $B M C$ Bioinformatics 2007, 8 (1), 263.

[102] Mikut, R.; Hilpert, K. Interpretable Features for the Activity Prediction of Short Antimicrobial Peptides Using Fuzzy Logic. Int. J. Pept. Res. Ther. 2009, 15 (2), 129-137.

[103] Diehnelt, C. W. Peptide Array Based Discovery of Synthetic Antimicrobial Peptides. Front. Microbiol. 2013, 4, 402.

[104] Phage Display: A Practical Approach: (A Practical Approach Series); Oxford University Press, 2004.

[105] Li, S.; Roberts, R. W. A Novel Strategy for In Vitro Selection of Peptide-Drug Conjugates. Chem. Biol. 2003, 10 (3), 233-239.

[106] Rice, J. J.; Schohn, A.; Bessette, P. H.; Boulware, K. T.; Daugherty, P. S. Bacterial Display Using Circularly Permuted Outer Membrane Protein OmpX Yields High Affinity Peptide Ligands. Protein Sci. 2006, 15 (4), 825-836.

[107] Lindner, T.; Kolmar, H.; Haberkorn, U.; Mier, W. DNA Libraries for the Construction of Phage Libraries: Statistical and Structural Requirements and Synthetic Methods. Molecules 2011, 16 (2), 1625-1641.

[108] Sidhu, S.; Gayer, C. Phage Display In Biotechnology and Drug Discovery. In; CRC Press, 2005; p 768.

[109] New England BioLabs. Ph.D. Phage display libraries. Protein tools https://www.neb.com/ /media/Catalog/AllProducts/DE54201237D74AE9BCBD5F99D079E B7D/Datacards or Manuals/manualE8110.pdf.

[110] Sergeeva, A.; Kolonin, M. G.; Molldrem, J. J.; Pasqualini, R.; Arap, W. Display Technologies: Application for the Discovery of Drug and Gene Delivery Agents. Adv. Drug Deliv. Rev. 2006, 58 (15), 1622-1654.

[111] Newell, D. G.; Fearnley, C. Sources of Campylobacter Colonization in Broiler Chickens. Appl. Environ. Microbiol. 2003, 69 (8), 43434351. 
[112] Bishop-Hurley, S. L.; Rea, P. J.; McSweeney, C. S. Phage-Displayed Peptides Selected for Binding to Campylobacter Jejuni Are Antimicrobial. Protein Eng. Des. Sel. 2010, 23 (10), 751-757.

[113] Pini, A.; Giuliani, A.; Falciani, C.; Runci, Y.; Ricci, C.; Lelli, B.; Malossi, M.; Neri, P.; Rossolini, G. M.; Bracci, L. Antimicrobial Activity of Novel Dendrimeric Peptides Obtained by Phage Display Selection and Rational Modification. Antimicrob. Agents Chemother. 2005, 49 (7), 2665-2672.

[114] Yacoby, I.; Shamis, M.; Bar, H.; Shabat, D.; Benhar, I. Targeting Antibacterial Agents by Using Drug-Carrying Filamentous Bacteriophages. Antimicrob. Agents Chemother. 2006, 50 (6), 2087-2097.

[115] Guralp, S. A.; Murgha, Y. E.; Rouillard, J.-M.; Gulari, E. From Design to Screening: A New Antimicrobial Peptide Discovery Pipeline. PLoS One 2013, 8 (3), e59305.

[116] Tominaga, T.; Hatakeyama, Y. Determination of Essential and Variable Residues in Pediocin PA-1 by NNK Scanning. Appl. Environ. Microbiol. 2006, 72 (2), 1141-1147.

[117] Xie, Q.; Matsunaga, S.; Wen, Z.; Niimi, S.; Kumano, M.; Sakakibara, Y.; Machida, S. In Vitro System for High-Throughput Screening of Random Peptide Libraries for Antimicrobial Peptides That Recognize Bacterial Membranes. J. Pept. Sci. 2006, 12 (10), 643-652.

[118] Willemson, T.; Hagemann, U.; Jouaux, E. Molecular Biomethods Handbook; springer science, 2008.

[119] Deslouches, B.; Phadke, S. M.; Lazarevic, V.; Cascio, M.; Islam, K.; Montelaro, R. C.; Mietzner, T. A. De Novo Generation of Cationic Antimicrobial Peptides: Influence of Length and Tryptophan Substitution on Antimicrobial Activity. Antimicrob. Agents Chemother. 2005, 49 (1), 316-322.

[120] Tan, J.; Huang, J.; Huang, Y.; Chen, Y. Effects of Single Amino Acid Substitution on the Biophysical Properties and Biological Activities of an Amphipathic A-Helical Antibacterial Peptide against Gram-Negative Bacteria. Molecules 2014, $19(8), 10803-10817$.

[121] Jin-Jiang, H.; Jin-Chun, L.; Min, L.; Qing-Shan, H.; Guo-Dong, L. The Design and Construction of K11: A Novel A-Helical Antimicrobial Peptide. Int. J. Microbiol. 2012, 2012, 764834.
[122] He, J.; Eckert, R.; Pharm, T.; Simanian, M. D.; Hu, C.; Yarbrough, D. K.; Qi, F.; Anderson, M. H.; Shi, W. Novel Synthetic Antimicrobial Peptides against Streptococcus Mutans. Antimicrob. Agents Chemother. 2007, 51 (4), 1351-1358.

[123] Cirino, P.; Qian, S. Synthetic Biology: Tools and Applications. In; Academic Press, 2013; p 352.

[124] Keefe, A. D.; Szostak, J. W. Functional Proteins from a Random-Sequence Library. Nature 2001, 410 (6829), 715-718.

[125] Fuda, C. The Basis for Resistance to -Lactam Antibiotics by Penicillin-Binding Protein 2a of Methicillin-Resistant Staphylococcus Aureus. $J$. Biol. Chem. 2004, 279 (39), 40802-40806.

[126] Mishra, B.; Leishangthem, G. D.; Gill, K.; Singh, A. K.; Das, S.; Singh, K.; Xess, I.; Dinda, A.; Kapil, A.; Patro, I. K.; Dey, S. A Novel Antimicrobial Peptide Derived from Modified NTerminal Domain of Bovine Lactoferrin: Design, Synthesis, Activity against Multidrug-Resistant Bacteria and Candida. Biochim. Biophys. Acta 2013, 1828 (2), 677-686.

[127] Schibli, D. J.; Hwang, P. M.; Vogel, H. J. Structure of the Antimicrobial Peptide Tritrpticin Bound to Micelles: A Distinct Membrane-Bound Peptide Fold. Biochemistry 1999, 38 (51), 16749-16755.

[128] Sitaram, N.; Subbalakshmi, C.; Nagaraj, R. Indolicidin, a 13-Residue Basic Antimicrobial Peptide Rich in Tryptophan and Proline, Interacts with $\mathrm{Ca}(2+)$-Calmodulin. Biochem. Biophys. Res. Commun. 2003, 309 (4), 879-884.

[129] Yau, W. M.; Wimley, W. C.; Gawrisch, K.; White, S. H. The Preference of Tryptophan for Membrane Interfaces. Biochemistry 1998, 37 (42), 1471314718.

[130] Deslouches, B.; Steckbeck, J. D.; Craigo, J. K.; Doi, Y.; Mietzner, T. A.; Montelaro, R. C. Rational Design of Engineered Cationic Antimicrobial Peptides Consisting Exclusively of Arginine and Tryptophan, and Their Activity against MultidrugResistant Pathogens. Antimicrob. Agents Chemother. 2013, 57 (6), 2511-2521.

[131] Deslouches, B.; Steckbeck, J. D.; Craigo, J. K.; Doi, Y.; Burns, J. L.; Montelaro, R. C. Engineered Cationic Antimicrobial Peptides to Overcome Multidrug Resistance by ESKAPE Pathogens. Antimicrob. Agents Chemother. 2015, 59 (2), 1329-1333. 
[132] McClean, S.; Beggs, L. B.; Welch, R. W.

Antimicrobial Activity of Antihypertensive Food-

Derived Peptides and Selected Alanine Analogues.

Food Chem. 2014, 146, 443-447.

[133] Alvarez-Ordóñez, A.; Begley, M.; Clifford, T.;

Deasy, T.; Considine, K.; Hill, C. Structure-

Activity Relationship of Synthetic Variants of the Milk-Derived Antimicrobial Peptide as2-Casein

f(183-207). Appl. Environ. Microbiol. 2013, 79

(17), 5179-5185.

[134] Mikut, R.; Reischl, M. Data-Based Activity

Analysis and Interpretation of Small Antibacterial

Peptides. Proc. 18th 2008. 